\section{SOI: $1.1 /$ TAS DOI: $10.15863 /$ TAS International Scientific Journal Theoretical \& Applied Science}

\author{
p-ISSN: 2308-4944 (print) e-ISSN: 2409-0085 (online) \\ Year: 2017 Issue: 03 Volume: 47 \\ Published: $30.03 .2017 \quad$ http://T-Science.org
}

Ahmed Butt Iftikhar
Dr., Associate Professor,
University of Kotli Azad Jammu \& Kashmir
(Pakistan)
butt_uck@yahoo.co.uk
Faran Iftikhar
MPhil student,

Faran.iftikhar@yahoo.com

SECTION 27. Transport.

\title{
FACTORS INFLUENCING THE LIKENESS OF IMPORTED AND LOCAL CARS
}

\begin{abstract}
This is a field based exploratory study around automobile industry of Pakistan. The aim of this research was to identify and evaluate the key factors that were influencing the likeness of imported and local cars in general public. To conduct this research, a structured questionnaire wasprepared to collect data from various car owners and potential buyers from selected areas of Pakistan. The structured nature of the investigation around hundreds of respondents generated a large amount of quantitative data. Statistical Package for Social Sciences (SPSS) was applied for the analysis of the data. The results indicate that although the trend of purchasing imported cars is increasing day by day but still the local car industry is dominant. The interesting finding is that the respondents acknowledged and favored the durability, comfort-ability, and innovative features of imported cars over local cars but still they are purchasing local cars to reduce the cost of after sale services and to have more resale value.The extreme likeness of imported cars indicates that they can easily compete the local car industry by simply reducing import costs and by providing reasonable after sales services. The resale value of imported cars will automatically increase when after sale services for imported cars will be up to the mark.This study clearly indicates that although local cars are dominant because of their resale value and reasonable after sales services but the trend of switching from local to imported cars is increasing day by day because of the innovative features and latest models of imported cars.

Key words: imported cars, automobile industry of Pakistan.

Language: English

Citation: Iftikhar AB, Iftikhar F (2017) FACTORS INFLUENCING THE LIKENESS OF IMPORTED AND LOCAL CARS. ISJ Theoretical \& Applied Science, 03 (47): 143-173.

Soi: http://s-0-i.org/1.1/TAS-03-47-25 Doi: crossef https://dx.doi.org/10.15863/TAS.2017.03.47.25
\end{abstract}

\section{Introduction of Auto Industry}

Auto industry is referred to as 'Industry of Industries' in the developed world. The auto industry of many regional countries is playing a vital role in transforming those countries into economic tigers.Pakistan is amongst the group of 40 countries in the world that produce automobiles. The Automotive industry is one of Pakistan's growing industries dominated by Japanesemanufacturer's, most of whom have their plants in the country. Pakistan's market is considered among the smallest but the fastest growing in South Asia, with 180,000 cars were sold in the 2014-15 fiscal year, rising to 206,777 units during 2015-16 fiscal year. The auto policy passed on March 19, 2016, offers tax incentives to new entrants to help them establish manufacturing units. In response, RenaultNissan, Kia Motors and Audi have expressed interest in entering the Pakistani automobile industry. The local market is dominated by three Japanese automobile companies Toyota, Honda and Suzuki. Two of them have assembly plants in Karachi and Honda has its plant in Lahore, all co-owned with local partners.

The production data analysis of all the subsectors revealed that the growth of production remained negative over the period of 2006-07 to 2015-16. At the same time the imports of Pakistan in auto industry has increased, which shows inverse relationship between production of domestic vehicles and parts and import of vehicles and auto parts;average sales value of Rs 1.5 million per unit and import of 36,000 vehicles per year.

\section{Background}

According to Ministry of Industries, Pakistan produced its first vehicle in 1953, at the National Motors Limited, established in Karachi to assemble Bedford Trucks. Subsequently buses, light trucks and cars were assembled at the same plant. The industry 
was highly regulated until the early 1990s. After deregulation, major Japanese manufacturers entered in the market and created some competition in this sector. Assemblers of Hino Trucks, Suzuki Cars (1984), Mazda Trucks, Toyota (1993) and Honda (1994), entered once deregulation was introduced.
Assembly of Daihatsu and Hyundai cars (1999) and various brands of LCVs and range of mini-trucks commenced recently. Following are the some wellknown locally assembled car models and imported car Models:

\author{
Locally Assembled Cars \\ Suzuki (Wagon-R) \\ Suzuki (Liana) \\ Suzuki (Khyber/ Cultus) \\ Suzuki (Baleno) \\ Suzuki (Alto) \\ Suzuki (Swift) \\ Suzuki (Margalla) \\ Suzuki (Mehran) \\ Honda (Civic) \\ Honda (City) \\ Toyota (Corolla XLI) \\ Toyota (Corolla GLI) \\ Toyota (Corolla ALTIS Grande) \\ Hyundai (Santro) \\ Nissan (Sunny) \\ Daihatsu (Cuore)
}

\section{Imported Cars}

Toyota Vitz

Toyota Aqua

Suzuki Every

Dihatsu Mira ES

Toyota Prius

Toyota Passo

DihatsuHijet Van

Toyota Land Cruiser Prado

Toyota Land Cruiser

Honda Fit Hybrid

Honda Vezel

Suzuki Alto

\section{Factors Influencing the Likeness of Imported and Local Cars}

Nowadays trend of imported cars is increasing. People are shifting their minds. Few years back people were not taking risks to buy imported vehicles but now there is an increasing trend for imported vehicles. Competition for local industry has been increased. Local industry is frequently launching new innovational models like imported cars to compete imported car industry. Mainly there are two types of cars: one is sedan and second is hatchback. Local industry is also launching new innovative model of sedan but still local industry is suffering in launch of hatchbacks at low cost, consequently trend of imported hatchback has been increased. Thisresearch has investigated the factors which influence the likeness of the imported and local vehicles. The research identified and investigated the lead factors which were playing their role in shaping buying behavior towards local and imported cars.

\section{Statement of the problem}

Buying behavior of customers towards local or imported cars depends on their potential satisfaction. Their satisfaction is influenced by a range of factors including price, quality, safety, durability and overall performance of the vehicle. The focus of this study is to identify and investigate the key factors which are playing their role in determining priorities for local or imported cars. The purpose of the research is to develop substantive understanding among automobile companies about buying trends and satisfaction parameters of customers towards local or imported cars. The findings will guide them in reshaping their marketing strategies to grow and succeed in the market.

\section{Previous research}

Noany previous research was found on similar topic in Pakistan. There were some researches related to auto industry with different directions and conclusions. So this research is unique in its nature and discovered some valued facts and figures about people's buying behavior and their level of satisfaction towards local and imported cars.

\section{Nature of the research}

It was exploratory research in its nature. The investigation wasundertaken through face to faceinterviews and questionnaire based field survey around a wide range of respondents. Interviews were conducted with dealers of local cars as well as with those who were inclined to import foreign cars.Thereafter an extensive questionnaire was designed and circulated among hundreds of respondents to collect their views about leading factors playing their role in shaping buying behavior and patterns among customers to have local or imported cars. The dual approach of gathering data gathering process through interviews and survey contributed a lot in getting diversified findings/results with different angles and perspectives. 


\section{Research questions and objectives}

After completing interviews and field survey, the research figured out some important relationships between dependent and independent variables. Drivervariables like age, gender, income, marital status, occupation, etc.have strong relationship with the research problem. Therefore, this research was designed to discover the relationship between our chosen variables based on pre-study to research and satisfaction for an existing car.The researchers figured out that there are some independent factors which affect the likeness of imported and local cars e.g. quality and satisfaction. Satisfaction depends on quality of car. Quality is an independent variable measuring the attributes of the car either local car is of good quality or imported one.
The driver variables (as referred above) drive the research in a particular direction. For example, our null hypothesis is a person who is earning handsome amount will go for imported car because he/she can bear risk of buying that car, but average earning person can't take that risk. Our research conclusion will tell us the true picture. The other question will be related to the risk factor which may resist customers to buy imported car. The most probably the answer to this question will be the lack of after sale service for imported cars. So it means there is a relationship between after sale service and satisfaction; therefore after sale service is another factor which affects the likeness of imported and local vehicle. The research measures the effects of independent variables with satisfaction level of car owner.

\section{Conceptual Model}

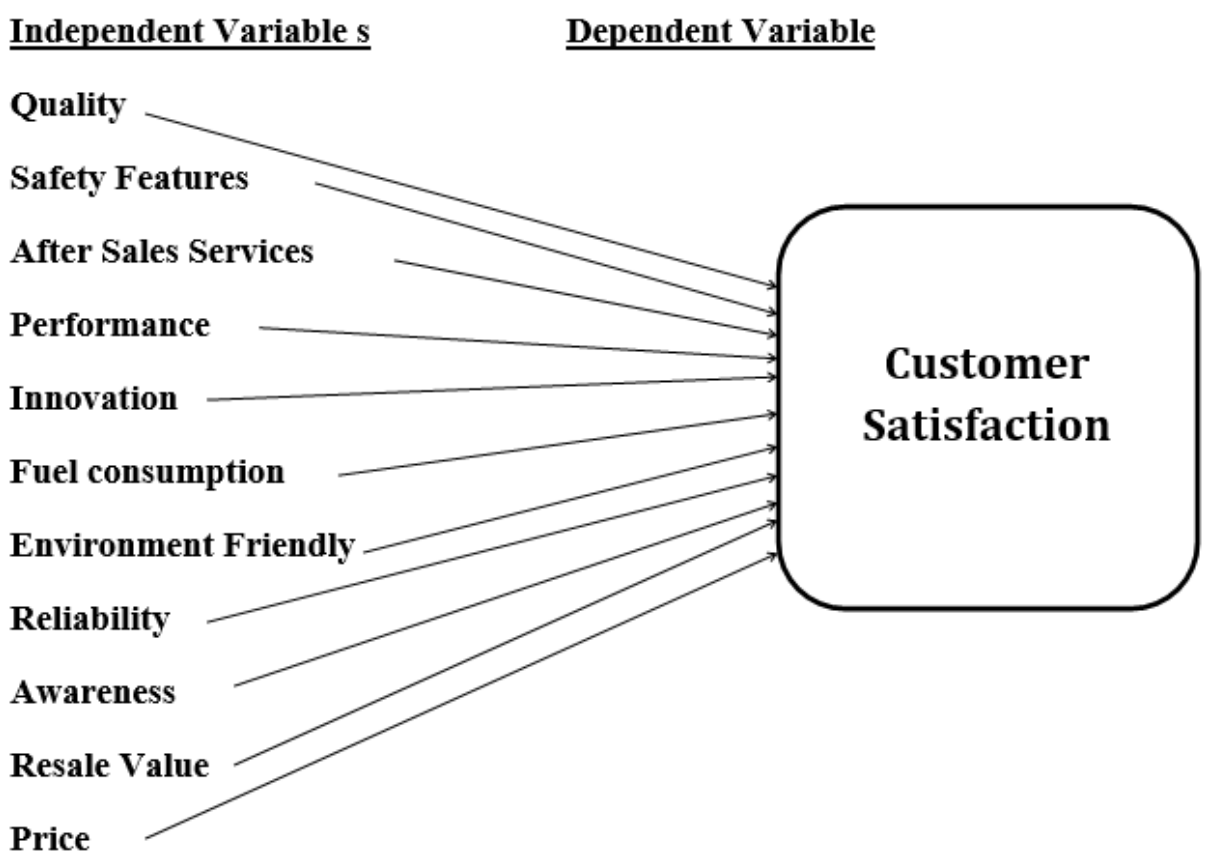

\section{Variables}

Driver variables and independent variables

These variables were drawn after an exploratory research (based on interviews) and literature reviews (facts and figures, auto policy). Initially the model included complicated and large number of variable which were interrelated but to squeeze or keep the questionnaire short, the researcher made logical relationships between some independent variables and dependent variables and excluded some extraneous relationships.

\subsection{Driver variables}

\subsubsection{Age}

Age is the main driver variable which has relationship between dependent and independent variables. It is so because lower the age, there will be lesserincome or pocket money. So low age customers are expected to have less costly cars. On the other hand, higher aged customers who are married and have large family size would prefer car having maximum seating capacity. Nowadays youth is tech driven or attracts towards the technology. They always prefer cars having more technological operations. 


\begin{tabular}{|c|c|c|c|c|c|c|}
\hline Impact Factor: & $\begin{array}{l}\text { ISRA (India) } \\
\text { ISI (Dubai, UAE } \\
\text { GIF (Australia) } \\
\text { JIF }\end{array}$ & $\begin{array}{r}=1.344 \\
=0.829 \\
=0.564 \\
=1.500\end{array}$ & $\begin{array}{l}\text { SIS (USA) } \\
\text { PИНЦ (Russia) } \\
\text { ESJI (KZ) } \\
\text { SJIF (Morocco) }\end{array}$ & $\begin{array}{l}=0.912 \\
=0.234 \\
=1.042 \\
=\mathbf{2 . 0 3 1}\end{array}$ & $\begin{array}{l}\text { ICV (Poland) } \\
\text { PIF (India) } \\
\text { IBI (India) }\end{array}$ & $\begin{array}{l}=6.630 \\
=1.940 \\
=4.260\end{array}$ \\
\hline
\end{tabular}

\subsubsection{Gender}

Our society is male dominant society. A family will have a car which was purchased by the decision of male member. On the other hand, females avoid going for maintenance of car on weekly or monthly basis so they will buy the new car which serves them in long term.

\subsubsection{Income}

It is another driver variable which tellsabout the capacity of person to buy new or used car. He will buy risky imported car or locally assembled new or used car. Income of person also tells us that how much person is conscious about the fuel consumption,maintenance cost, cost of spare parts of a car etc.

\subsubsection{Family type}

If there will be joint family system than they will have more than 1 vehicle or 7 seated vehicle. Now they will do market research which 7 seatedvehicle is more comfortable and durable imported or local. If there will be nuclear family system, then they might go for two door hatchback or sports car depends on their decision. They may also go for less engine power vehicle.

\subsubsection{Marital status, number of family members}

Like family type, the choice and preferences to buy a car differ with marital status and number of family members.

\subsubsection{Occupation}

It is another basic driver variable. Income case applies here e.g. if person have its own business he may afford luxury cars. So he might have unique opinion for that specific high model either for imported or local. If a person is employed in small organization he will prefer a car which is more economical and have good fuel consumption.

\subsection{Independent variables}

\subsubsection{Quality}

It is the main independent variable. Quality mainly depends on finishing of car, instruments used in and attributes or characteristics of that car. Quality also depends on comfort-ability(Auto, power seats, retractable power mirrors \& windows, push start, external locking).So it has direct relationship with satisfaction level of a car. So this research will tell us which car is of best in quality - imported or local.

\subsubsection{Performance}

Performance is another independent variable. The research revealed that people are inclined to compare the cars' performance on different basis. They compare the cars on the basis ofthe network where they drive. For example, our null hypothesis is: people prefer sedan cars with good performanceon highways as compared with the city drive. People compare which car performs better having same engine power. Either $1000 \mathrm{cc}$ imported car performs better or 1000cc Local car. So performance depends on durability, engine performance and type of drive of a car.

\subsubsection{Safety features}

Now in $21^{\text {st }}$ century, world is forcing auto company to bring as much safety features as they can. So to measure safety features in a car ABS (Antilock Braking System) new enhanced breaking technology which stops the car very quickly with minimum jerk. Airbags have become a basic safety feature which comes out from steering during accidents keeps driver and other passengers safe from fatal injuries. Cruise control is control of maximum speed. The driver sets the maximum speed of car during drive so that car does not cross that level and very indeed security system. It keeps the car safe from thieves.In short, more the safety features more the satisfaction level of owner for that particular car.

\subsubsection{Innovation}

Innovation is all what customers eagerly wait for in any product. So same is the case with auto industry. This is human nature that he/she attracts towards new and innovative things. Auto transmission, Hybrid technology, Power steering, Push start, Remote based or Keyless entry, Eco Idle feature and climate control are some features which tell us how much vehicle is innovative according to $21^{\text {st }}$ century which brings satisfaction for the owning vehicle in the mind of owner.

\subsubsection{Resale factor}

Resale is another factor which has direct connection with likeness of imported or local vehicle or it affects the decision of purchase of imported and local car. Some people are very conscious about resale value of car and some prefer brand and some go for the features of the car. So this is also a result driven approach. 


\begin{tabular}{|c|c|c|c|c|c|c|}
\hline Impact Factor: & $\begin{array}{l}\text { ISRA (India) } \\
\text { ISI (Dubai, UAF } \\
\text { GIF (Australia) } \\
\text { JIF }\end{array}$ & $\begin{array}{l}=1.344 \\
=0.829 \\
=0.564 \\
=1.500\end{array}$ & $\begin{array}{l}\text { SIS (USA) } \\
\text { PИНЦ (Russia) } \\
\text { ESJI (KZ) } \\
\text { SJIF (Morocco) }\end{array}$ & $\begin{array}{l}=0.912 \\
=0.234 \\
=1.042 \\
=\mathbf{2 . 0 3 1}\end{array}$ & $\begin{array}{l}\text { ICV (Poland) } \\
\text { PIF (India) } \\
\text { IBI (India) }\end{array}$ & $\begin{array}{l}=6.630 \\
=1.940 \\
=4.260\end{array}$ \\
\hline
\end{tabular}

\subsubsection{After sales services}

Availability of mechanics, spare parts and price of spare partsdetermine quality of after sale services being provided by the company. Furthermore, after sale services of local vehicles are easily available or not and what sort of after sale services of imported cars aremore important for owners of these vehicles.

\subsubsection{Fuel consumption}

This will tell us whether our respondent is satisfied with the fuel consumption of imported car or local car, or which car gives better millage than other. As revealed by our exploratory research nowadays this is a major concern of customers while buying any car.

\subsubsection{Price}

Last but not least, price is a unique factor which is dependent as well as independent. It is independent because satisfaction of owner depends on price which is independent variable. On the other hand, price depends on all other features respondent will consider but in less price. So price to features ratio determines which car gives a lot of features in minimum price than other. The researchers have made a 3 price brackets in thequestionnaire which will determine that what people prefer in that specific price range. So it will give us interesting figures.

\section{Method of the study}

Mixed method of research design was adopted because the purpose of this study was to examine the factors that were Influencing the likeness of imported and local cars. Though many inquiry forms could have beenused, but this mixed design was the most appropriate for the completion of the task. It was easy and comfortable with respect to time saving and for analysis of the received data.

\subsection{Target Population/Respondents}

The participants were the university students and employees who owned a car either imported or local. Other than university, questionnaires were filled by several government and public sector employees, businessmen, lawyers, car dealers, bankers etc. In addition through online questionnaire we got random respondents from all over the Pakistan belonging do different fields. Close-ended questions were asked to get quantitative data.

\subsection{Sampling Frame}

The sampling frame or working population for this study wasthe car owners from all over the Pakistan. We targeted University students and employees on first priority basis. Then we got questionnaires filled by friends and family. Due to lack of time it was not possible to approach respondents from all over the Pakistan in this short time, so through online questionnaire we got respondents from all over the Pakistan. Questionnaires were also filled by different car dealers based in Islamabad after undertaking their interviews.

\subsection{Sample Size}

We planned to get $100+$ questionnaires filled by random respondents including students, employed and unemployed car owners, government servants and businessmen from different urban and rural areas of Pakistan. It was anticipated that by simply following the random sampling procedures, we will achieve our desired results without any effort given to purposely selecting men or women, employed or unemployed to balance the study.

\subsection{Sample Unit}

Sampling units were the car owners selected using the random sampling method outlined below in sampling methods and sampling procedures.This survey is the combination of nominal, ordinal, category and constant some scale. This survey was administered by using random sampling method throughout Pakistan.

\subsection{Sampling Method}

Simple random sampling (also referred to as random sampling) was used to collect data from different car owners. Each member of population irrespective of age, gender, occupation, employment status, income etc. has equal chance to be chosen as part of the sample. The logic behind simple random sampling is that itremoves any biasness. We randomly distributed questionnaires among students, university employees, businessmen, lawyers, bankers and many other respondents from different fields and occupations. We personally visited some car showrooms in Islamabad and got the responses of Imported and Local car dealers through questionnaires. We made sure that the respondent completely understands the questions by explaining the questionnaire to respondents who were confused about some questions.

During our visit to car showrooms in Islamabad we had an extensive discussion with dealers of imported and local cars about the current purchasing trend of imported and local cars and the factors that are influencing the customers purchase decision to 
buy an imported or a local car.We also created an online questionnaire to target those car owners to whom we were unable to distribute questionnaires because they were from other cities of Pakistan. We searched famous blogs, forums and social media groups related to auto industry and shared the link of our online questionnaire in those groups. We got a huge response through online questionnaire.

\section{Online} Questionnaire

Link: https://www.goo.gl/ZQKxBY

\subsection{Sampling Procedure}

a) $\mathrm{We}$ distributed questionnaires randomly among the university students and employees.

b) Each member personally visited some of his family and friends who owned a car and got the questionnaire filled by them.

c) The respondents were properly guidedabout questionnaire so they were more comfortable while filling the questionnaire.

d) The link of online questionnaire was shared in renowned blogs, forums and social media groups related to auto industry.

e) The link of online questionnaire was also shared with family members and friends, who were far away, through WhatsApp and Facebook.

f) Group members managed to visit some renowned showrooms and administered extensive interviews and gathered detailed information.

\section{Questionnaire}

To introduce our questionnaire to the respondents we created a short cover letter and attached it to the front of each questionnaire. This short cover letter helped in giving the study an increased level of credibility which in return helped in achieving high response rate.

\section{Research Design}

This research was a field study and the research design was descriptive in nature. The study was undertaken in order to understand the factors that were influencing the likeness of imported and local cars in general public. The researchers utilized questionnaire as a primary data collection mode. It was realized that field study is appropriate for this research topic because researchers were interested in connecting the large number of car owners in a short span of time. The questionnaire method enabled the researchers to evaluate the large sample of population quickly at low cost.

The researchers also created an online questionnaire and shared it to different social media groups related to auto industry and in different forums of online websites to get maximumresponses from the public. We got random respondents from all over Pakistan through the online questionnaire. The link of online questionnaire was shared with all family members and friends on WhatsApp and Facebook to get maximum responses.

Other than questionnaire method, we conductedin-depth interviews from some renowned imported and local cars dealers in Islamabad for secondary data collection. Through these interviews we gathered a lot of information about customers' preferences and priorities about the car and the factors that were influencing their choice, either to buy local or imported cars.

We used quantitative research method instead of qualitative method because respondents were not willing to spend more time to fill up the questionnaire. We selected this method so that the respondent can easily respond us.

\section{Budget, Schedule and Resources}

This research had a modest budget of Rs.5000 that covered the cost of photocopies to produce the questionnaires, stationary expensesand fare for visiting different dealer showrooms in Islamabad. It took two weeks to get all the questionnaires filled. For in-depth interviews the researchers were already prepared about the queries to be asked from the dealers. They visited three renowned showrooms in Islamabad and met the car dealers and asked several questions related to the customer's buying behavior and priorities to buy a car and the factors that were influencing their choice, either to buy a local or imported car.

\section{Results}

We strived to meet at least $95 \%$ significance for all our tests. All of our analysis achieved the $95 \%$ significance level. Although we realized that everything with high significance level is not always relevant. Unless otherwise noted we stated only significant and relevant results. The table below summarizes general descriptive statistics of sample population. 


\begin{tabular}{|c|c|c|c|c|c|c|}
\hline Impact Factor: & $\begin{array}{l}\text { ISRA (India) } \\
\text { ISI (Dubai, UAE } \\
\text { GIF (Australia) } \\
\text { JIF }\end{array}$ & $\begin{array}{r}=1.344 \\
=0.829 \\
=0.564 \\
=1.500\end{array}$ & $\begin{array}{l}\text { SIS (USA) } \\
\text { PИHЦ (Russia) } \\
\text { ESJI (KZ) } \\
\text { SJIF (Morocco) }\end{array}$ & $\begin{array}{l}=0.912 \\
=0.234 \\
=1.042 \\
=\mathbf{2 . 0 3 1}\end{array}$ & $\begin{array}{l}\text { ICV (Poland) } \\
\text { PIF (India) } \\
\text { IBI (India) }\end{array}$ & $\begin{array}{l}=6.630 \\
=1.940 \\
=4.260\end{array}$ \\
\hline
\end{tabular}

Descriptive Statistics:The table summarizes general descriptive statistics of sample population.

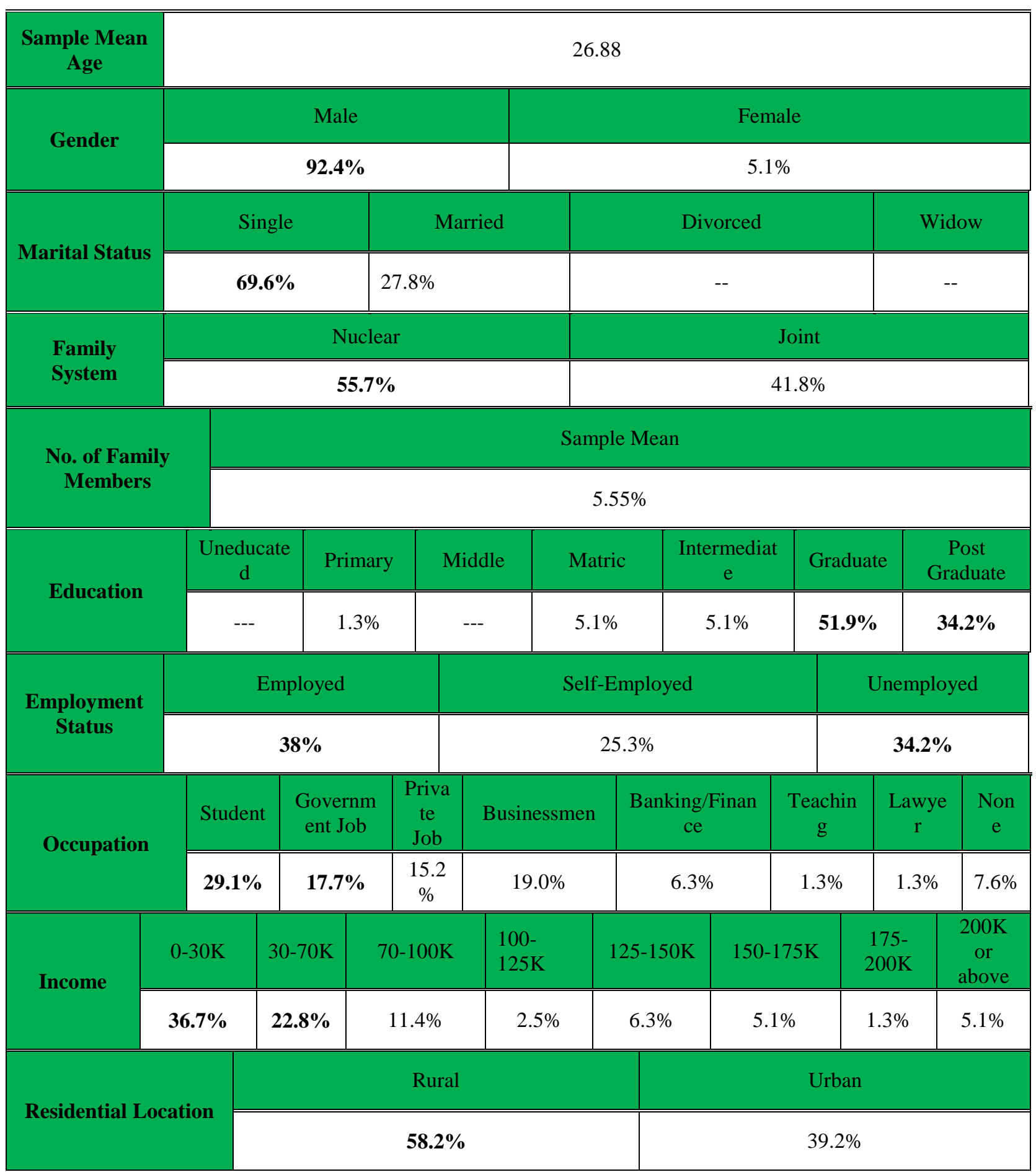

\section{Inferential Statistics}

\section{Anova}

$>$ Age to car you own

Method Used One-Way ANOVA; Sig $=.072$, [Appendix A].The result shows that the respondents from 20-26 years of age preferred to have an imported used car. On the other hand, Appendix A is showing that the respondents from 30 or above age either have a locally assembled new or used car.

\section{Marital Status to Features Given in less} price

Method Used One-Way ANOVA; Sig $=0.066$ [Appendix B]. There is a significant relationship between marital status and buying behavior towards local or imported car. Graph in Appendix B is 
showing that married persons were more inclined towards imported because of more features in less price compared to local cars but single persons were inclined towards local cars and they were less in favor of the statement that imported cars give more features with price.

\section{Family system}

Method Used One-Way ANOVA Sign=.033, [Appendix C]. The perception that buying a car is investment varies from joint to nuclear family system. According to Appendix C Joint families think buying a car is an investment but Nuclear have a mindset that buying a car is not investment. There can be reasons that Joint family members have responsibilities to feed whole family; whereas, nuclears have small family size so they don't think buying a car is an investment. This is also the reason that there is the significance relationship between family system and effects of resale value on purchase decision.

\section{Education to quality of imported car}

Method Used One-Way ANOVA. Sign=.062, [Appendix D]. There is a significant relationship between education and quality of imported car. As per Appendix D there is a mix and interesting trend. The people who are less educated think that quality of local car is satisfactory; same is the opinion of highly educated people. On the other-hand the respondents whose education is in progress or who have achieved some medium level of education were found of the opinion that quality of imported cars is highly satisfactory.

\section{features}

\section{Education to consciousness for safety}

Method Used One-Way ANOVA. Sign=.024, [Appendix E]. There is a very interesting relationship between education and consciousness for safety features. Appendix E is telling us that if a person is uneducated or just primary pass that person is less conscious about safety features in a car and vice versa. This may be because of less education and traditional thinking that he doesn't think about new safety features in car.

\section{Employment Status to Consciousness about Resale value \\ Method Used One-Way ANOVA. Sign: 0.082, [Appendix F]. There is a little but note-able significant relationship between above given variables. Salaried and Unemployed persons are more conscious about resale value of car because they have limited or low income as compared with those who are running their own businesses or self- employed. graph is given in Appendix F.}

\section{Occupation to Buying a car is Investment}

Method Used One-Way ANOVA. Sign: 0.098, [Appendix G]. There is a significant relationship between occupation and thinking of people either buying a car is investment or not. There is mix trend but it is clear that no one strongly agreed that buying a car is an investment except teachers. Graph is attached in Appendix $G$ which is telling us that a person is earning higher slabs of income doesn't care much about resale value of car.

\section{Monthly Income to Effect of Resale value on purchase decision}

Method Used One-Way ANOVA; Sig $=0.010$, [Appendix H]. It means there is a significant relationship between what people earn and effect of resale value on purchase decision. According to appendix 20 the persons who have lower income, there purchase decision mainly depends on resale value of car and those who have higher income level, there purchase decisions are not affected by resale value of car. It means Lower income people also think that buying a car is an investment and they will not purchase out of market car either it is imported or local.

\section{Million \\ Monthly Income to car purchase in 2 \\ Method used ANOVA. Sign: 0.014, [Appendix} I]. It means there is a significant and important relationship between these two above given variables. According to Appendix 2 the person whose income is low thinks that if he/she has two million he/she would go for new imported car but on the other-hand the people who are earning handsome amount they prefer new local assembled car. It has already explained that local industry is launching new and innovative models but in sedans with higher price bracket so people don't go for imported car if they have 2 million. It is so because that they don't face any issue in after sale service for local cars. car

\section{Residential Location to Quality of Local}

Method Used One-Way ANOVA. Sig: 0.007, [Appendix I]. According to appendix I there is a significant relationship between residential location and quality of local car. Urban say quality of local cars is just satisfactory but rural based customers think that quality of local cars is dissatisfactory. It means marketing team of local industries should consider the views of rural customers.

\section{Frequencies}

\section{$>$ Car you own}

According to Appendix 1,people have 35\% locally assembled new cars, $31 \%$ have imported used cars and $29 \%$ have locally assembled used car. It 
means the market is still dominant of local assembled used and new cars. The results also show us that people don't import new cars because their cost is high.

\section{$>$ Car Company and Model}

According to Appendix 2, the results are revealing that $34.21 \%$ of people have Suzuki local assembled car while $19.7 \%$ have Toyota imported cars and $16 \%$ have Honda local assembled cars and $15 \%$ have Toyota local cars it means Suzuki in Pakistan is dominating its competitors.

\section{$>$ Quality of Imported Cars}

According to Appendix 3, the results reveal that $51 \%$ of our respondents are highly satisfied with quality of imported cars and $38 \%$ are satisfied with quality of imported cars. It means people perceive that quality of imported cars is better compared to local ones. $\mathrm{s}$

\section{$>$ Quality of Local Cars}

According to Appendix 4, the results are showing that $53.25 \%$ of respondents are satisfied with the quality of local cars and $28 \%$ were not clear (Neutral) about the quality of local cars. It means most of the people are just satisfied with the quality of local cars. On the other hand, $51 \%$ of people are highly satisfied with the quality of imported cars.

\section{$>$ Comfortable and durable Cars}

According to Appendix 5,60\% of people were found of the opinion that imported cars were more durable and comfortable, while $29 \%$ said that both imported and local cars were comfortable and durable and $11 \%$ said local cars were more comfortable and durable.

\section{$>$ Consciousness of safety features and their priority Levels}

According to Appendix 6, the results reflect that $66 \%$ of people are highly conscious and $21 \%$ are conscious up to some extent about safety features in a car. 74 and $71 \%$ think that $\mathrm{ABS}$ and airbag respectively are their first priority in safety features. Furthermore $64 \%$ say cruise control is their 2 nd and 3 rd priority. In the case of cars security system, $58 \%$ of respondents see this safety feature as first priority, so it concludes that ABS, Airbag and Safety System are the major safety features which affect the people's behavior of buying a car.

\section{$>$ Car equipped with more safety features}

According to Appendix 7,82\% of people said that imported cars are equipped with more safety features. As in appendix 6, it has been informed that majority of the people are highly conscious about safety features and this result is revealing that imported cars have more safety features, so it is obvious fact that people prefer imported cars over local cars in case of safety features.

Buying a Car as an investment and consciousness about resale value of car

According to Appendix 8, the results are showing that $50 \%$ of people agree that buying a car is an investment, $29 \%$ were neutral about this. However, $53 \%$ of people are less conscious about the resale value of car but $33 \%$ are highly conscious about resale value of car. So to find interesting results we will briefly explain the relationship between these two questions in ANOVA technique. Appendix 9 is also giving hint that majority of the people are less conscious about the resale value of car. It means there is attractiveness for foreign investors to invest in Pakistan in auto industry. Newly established auto company can sell its product to Pakistani just by little efforts because buyer is conscious to some extent about the Resale value of car. It can also be the reason of emerging trend of imported vehicles in Pakistan. cities

$>$ Performance in hilly areas, highways and

According to Appendix 9, the results are showing that $36.8 \%$ of people think local car performs better in hilly areas and $31 \%$ says both imported and local cars perform better on hilly areas and $23 \%$ says imported cars are better in hilly areas than local cars.With respect to highways drive $46 \%$ people prefer imported Vehicles and 38\% says both imported and local cars perform equally on highways. With respect to cities people says imported car performs better in cities having $49 \%$ over local cars and 33\% says both imported and local cars perform equally with in a city

\section{$>$ Fuel Consumption}

According to appendix 10, 57\% are highly conscious about fuel consumption of vehicles and it was surprising that $29 \%$ remaining respondents are less conscious about fuel consumption of the vehicle.As per as fuel consumption on highways is concerned 58\% Respondents said imported cars consumes less fuel on highways and $20 \%$ said both are equal. Same is the case in city driving. It can be threat in near future for local industry that local cars are less fuel efficient in both type of driving conditions.Imported cars are double in number than local cars.

\section{$>$ Price to Features Ratio}

As shown inappendix 11, according to $75 \%$ of respondents, imported cars are giving more features than local cars which is a big figure and can be threat for local industry.12\% said local car gives more features in less price so appendix $\mathbf{1 2}$ is revealing that price is the basic factor which influence buyers towards imported cars. 


\begin{tabular}{|c|c|c|c|c|c|c|}
\hline Impact Factor: & $\begin{array}{l}\text { ISRA (India) } \\
\text { ISI (Dubai, UAF } \\
\text { GIF (Australia) } \\
\text { JIF }\end{array}$ & $\begin{array}{l}=1.344 \\
=0.829 \\
=0.564 \\
=1.500\end{array}$ & $\begin{array}{l}\text { SIS (USA) } \\
\text { PИНЦ (Russia } \\
\text { ESJI (KZ) } \\
\text { SJIF (Morocco }\end{array}$ & $\begin{array}{l}=\mathbf{0 . 9 1 2} \\
=\mathbf{0 . 2 3 4} \\
=\mathbf{1 . 0 4 2} \\
=\mathbf{2 . 0 3 1}\end{array}$ & $\begin{array}{l}\text { ICV (Poland) } \\
\text { PIF (India) } \\
\text { IBI (India) }\end{array}$ & $\begin{array}{l}=6.630 \\
=1.940 \\
=4.260\end{array}$ \\
\hline
\end{tabular}

\section{Conclusion}

Results of this study allowed us to know exactly about the factors that are influencing the likeness of imported and local cars.

$>$ The result indicates that, although the trend of purchasing imported cars is increasing day by day but still the local car industry is dominant.

This study clearly indicates that although local cars are dominant because of their resale value and reasonable after sales services but the trend of switching from local to imported cars is increasing day by day because of the innovative features and latest models of imported cars.

Lack of auto quality policy provides room for lack of implementation of safety and quality standards for vehicles in Pakistan.

There is an extreme likeness of imported cars because these cars are loaded with various features including $\mathrm{ABS}$ brakes, power steering, air bags etc. they are considered a very attractive and cost effective.

The after sale services of imported cars is non-existent and most of the times cars are left at the mercy of unskilled technicians for service and repairs.
The availability of spare parts at fixed prices and on the spot is non-existent in most of the cases. The cost of parts being imported from Japan or any other country is very high.

The research indicates that imported cars can easily compete the local car industry by simply reducing import costs and by providing reasonable after sale services. The resale value of imported cars will automatically increase when after sale services for imported cars will be provided.

$>$ The interested finding is that the respondents acknowledged and preferred the durability, comfortability, and innovative features of imported cars over local cars but still they are purchasing local cars to reduce the cost of after sale services and to have more resale value.

We found a significant relationship between the car respondent owns and the satisfaction level for his car. The results indicate that owners of Toyota imported cars are highly satisfied with their cars; whereas, owners of Toyota local cars are just satisfied.Owners of Honda imported cars are highly satisfied with the cars even more than the satisfaction level of Toyota imported cars.On the other hand the person who owns the Suzuki local cars were less satisfied with their cars. 


\begin{tabular}{|c|c|c|c|c|c|c|}
\hline Impact Factor: & $\begin{array}{l}\text { ISRA (India) } \\
\text { ISI (Dubai, UAF } \\
\text { GIF (Australia) } \\
\text { JIF }\end{array}$ & $\begin{array}{r}=1.344 \\
=0.829 \\
=0.564 \\
=1.500\end{array}$ & $\begin{array}{l}\text { SIS (USA) } \\
\text { PИНЦ (Russia) } \\
\text { ESJI (KZ) } \\
\text { SJIF (Morocco) }\end{array}$ & $\begin{array}{l}=0.912 \\
=0.234 \\
=1.042 \\
=2.031\end{array}$ & $\begin{array}{l}\text { ICV (Poland) } \\
\text { PIF (India) } \\
\text { IBI (India) }\end{array}$ & $\begin{array}{l}=6.630 \\
=1.940 \\
=4.260\end{array}$ \\
\hline
\end{tabular}

\section{Appendices providing above stated facts and figures are given below}

$\underline{\text { Appendix A }}$
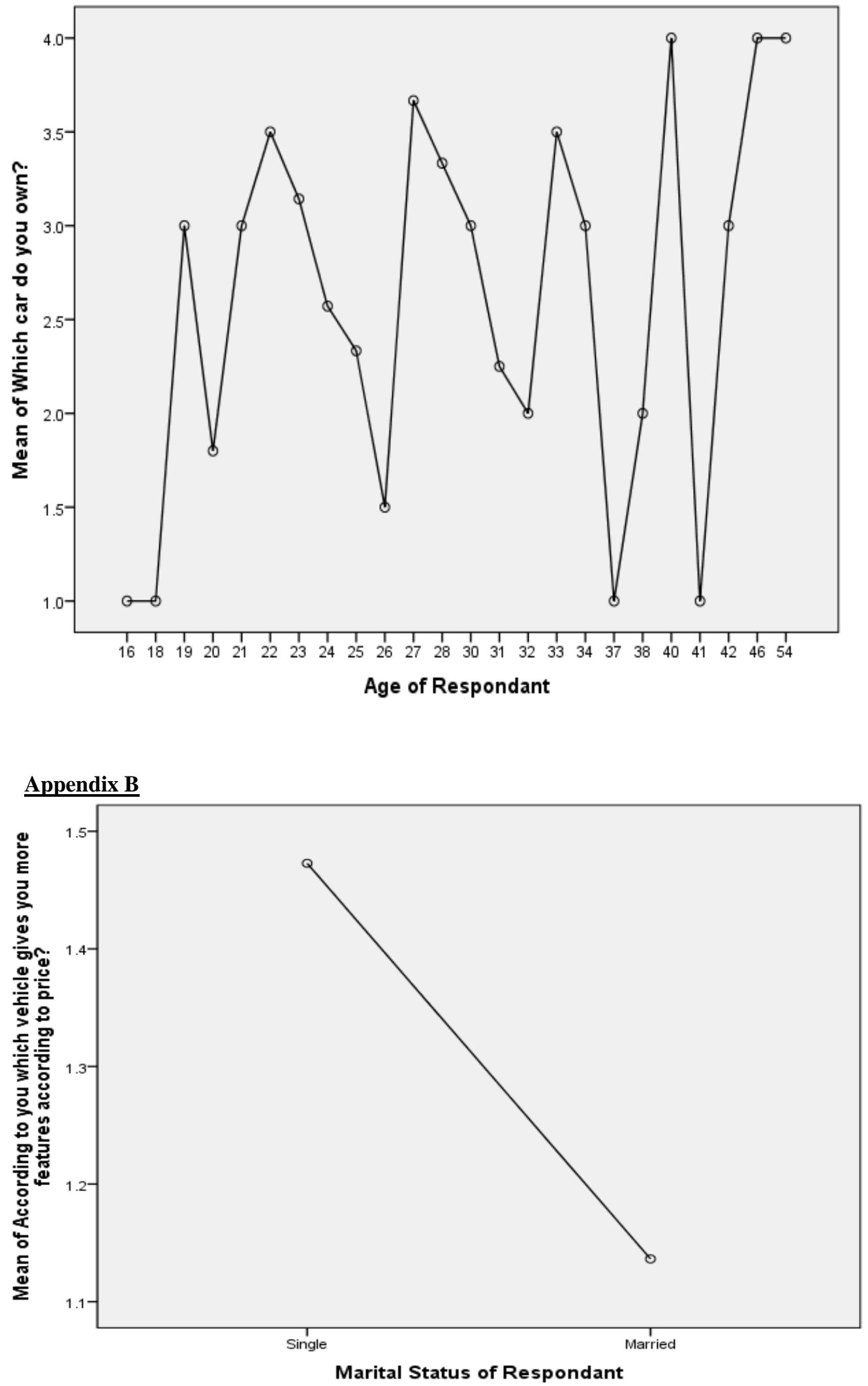


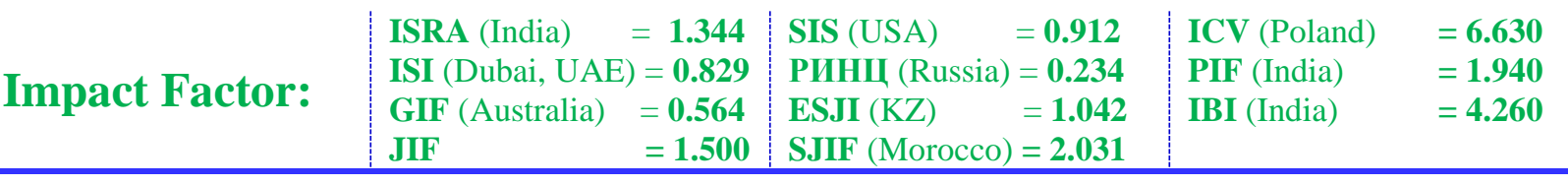

\section{$\underline{\text { Appendix C }}$}

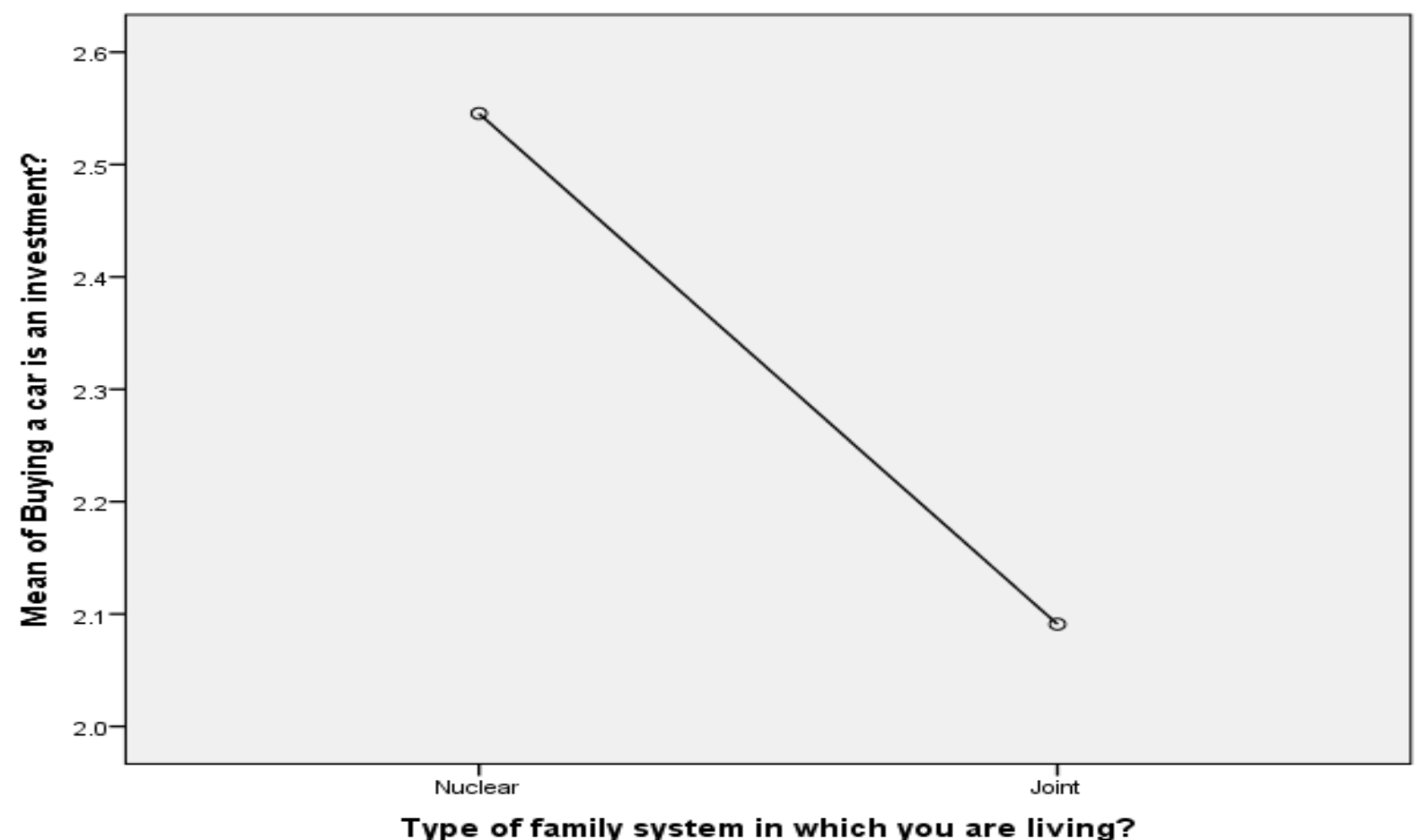

$\underline{\text { Appendix }} \underline{\underline{D}}$

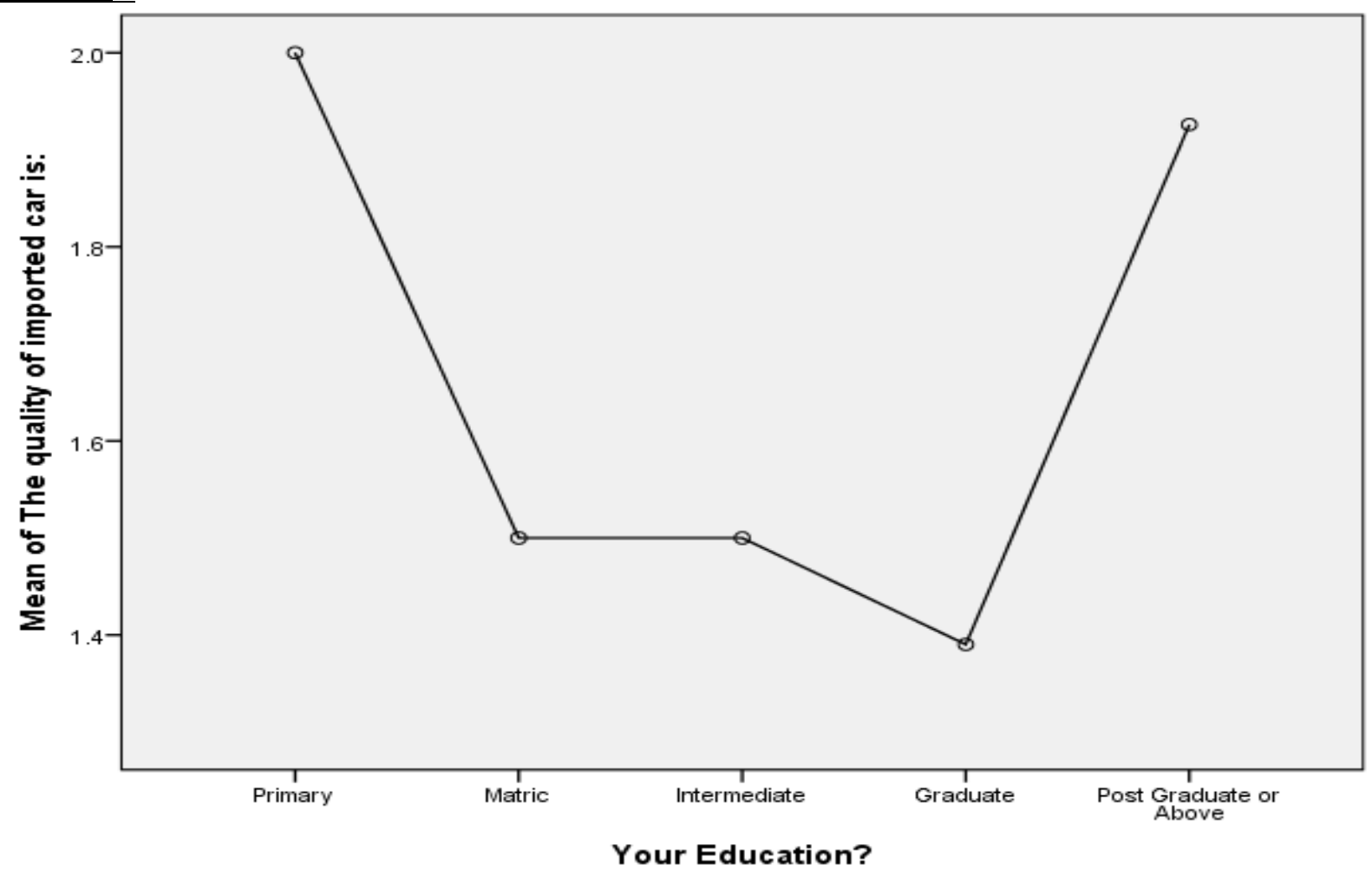




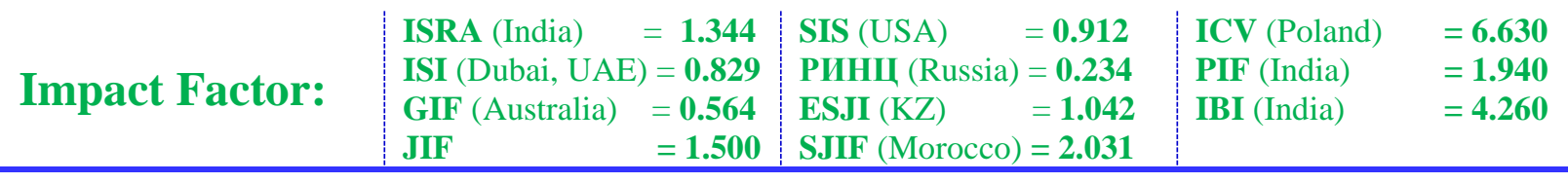

\section{$\underline{\text { Appendix E }}$}

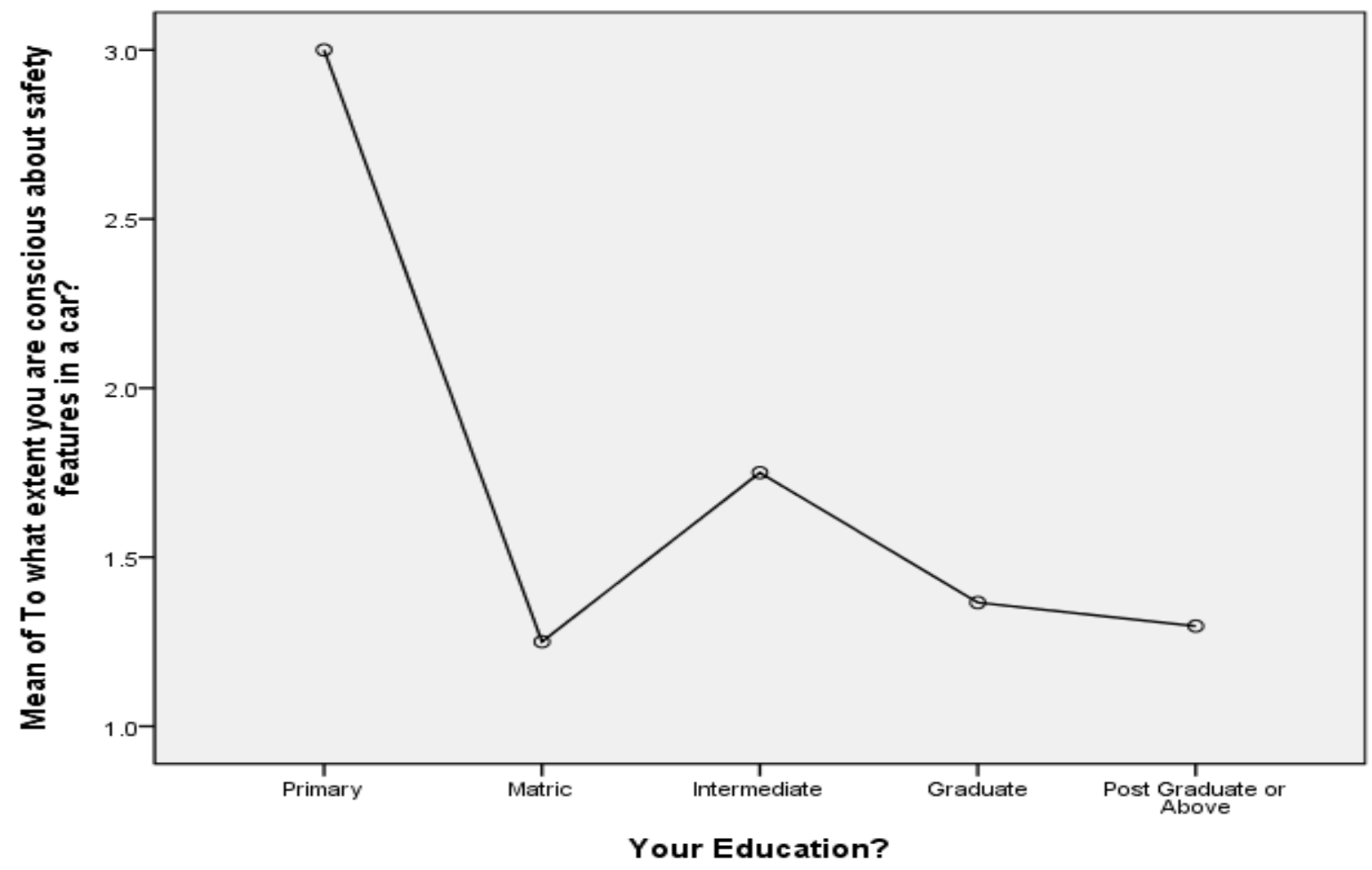

$\underline{\text { Appendix F }}$

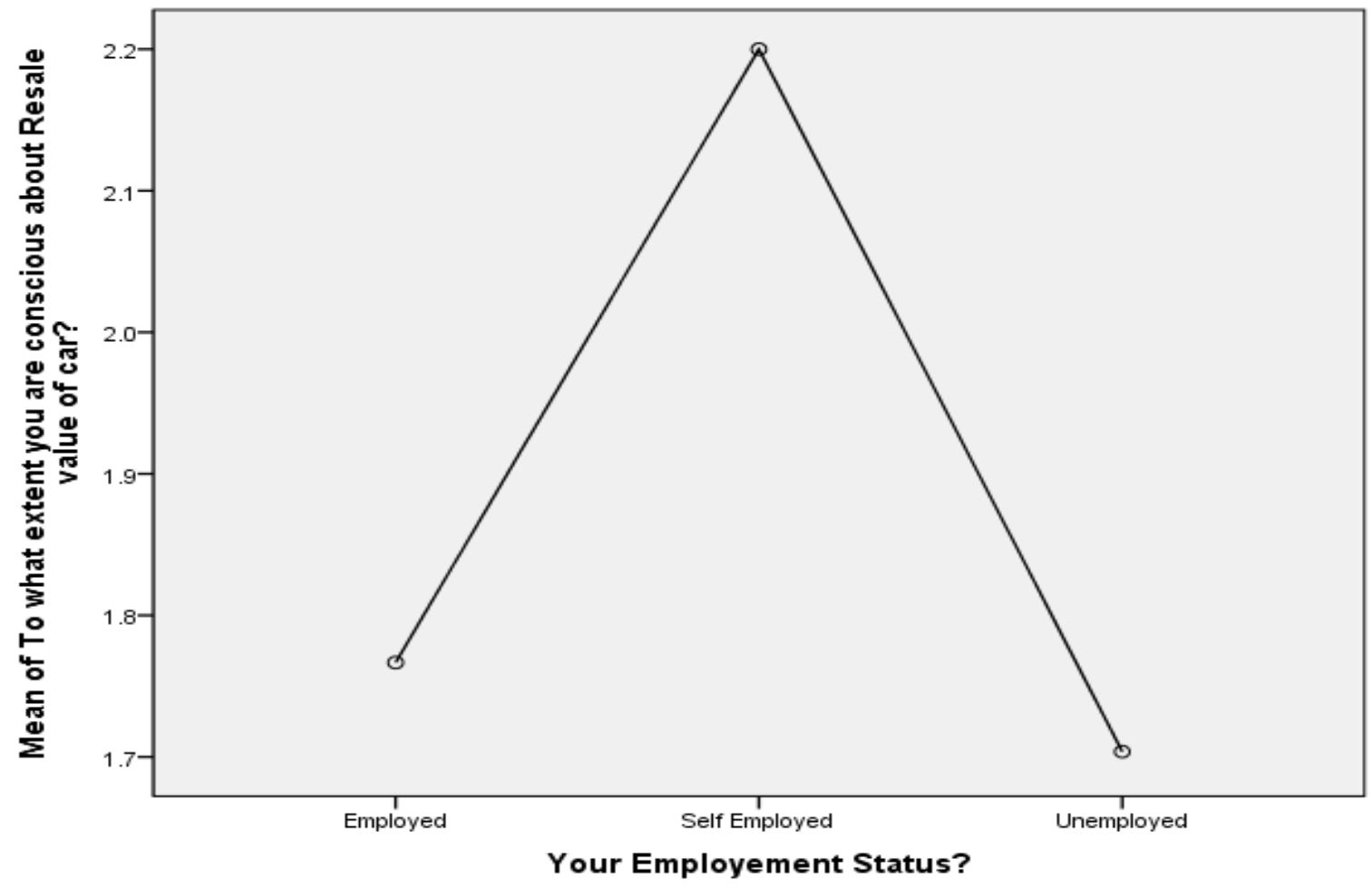




\begin{tabular}{l|lrl|l|ll} 
& ISRA (India) & $=\mathbf{1 . 3 4 4}$ & SIS (USA) & $=\mathbf{0 . 9 1 2}$ & ICV (Poland) & $=\mathbf{6 . 6 3 0}$ \\
Impact Factor: & ISI (Dubai, UAE) $=\mathbf{0 . 8 2 9}$ & PUHЦ (Russia) & $=\mathbf{0 . 2 3 4}$ & PIF (India) & $=\mathbf{1 . 9 4 0}$ \\
& GIF (Australia) & $\mathbf{0 . 5 6 4}$ & ESJI (KZ) & $=\mathbf{1 . 0 4 2}$ & IBI (India) & $=\mathbf{4 . 2 6 0}$ \\
& JIF & $\mathbf{1 . 5 0 0}$ & SJIF (Morocco) & $\mathbf{2 . 0 3 1}$ & & \\
\hline
\end{tabular}

\section{$\underline{\text { Appendix G }}$}

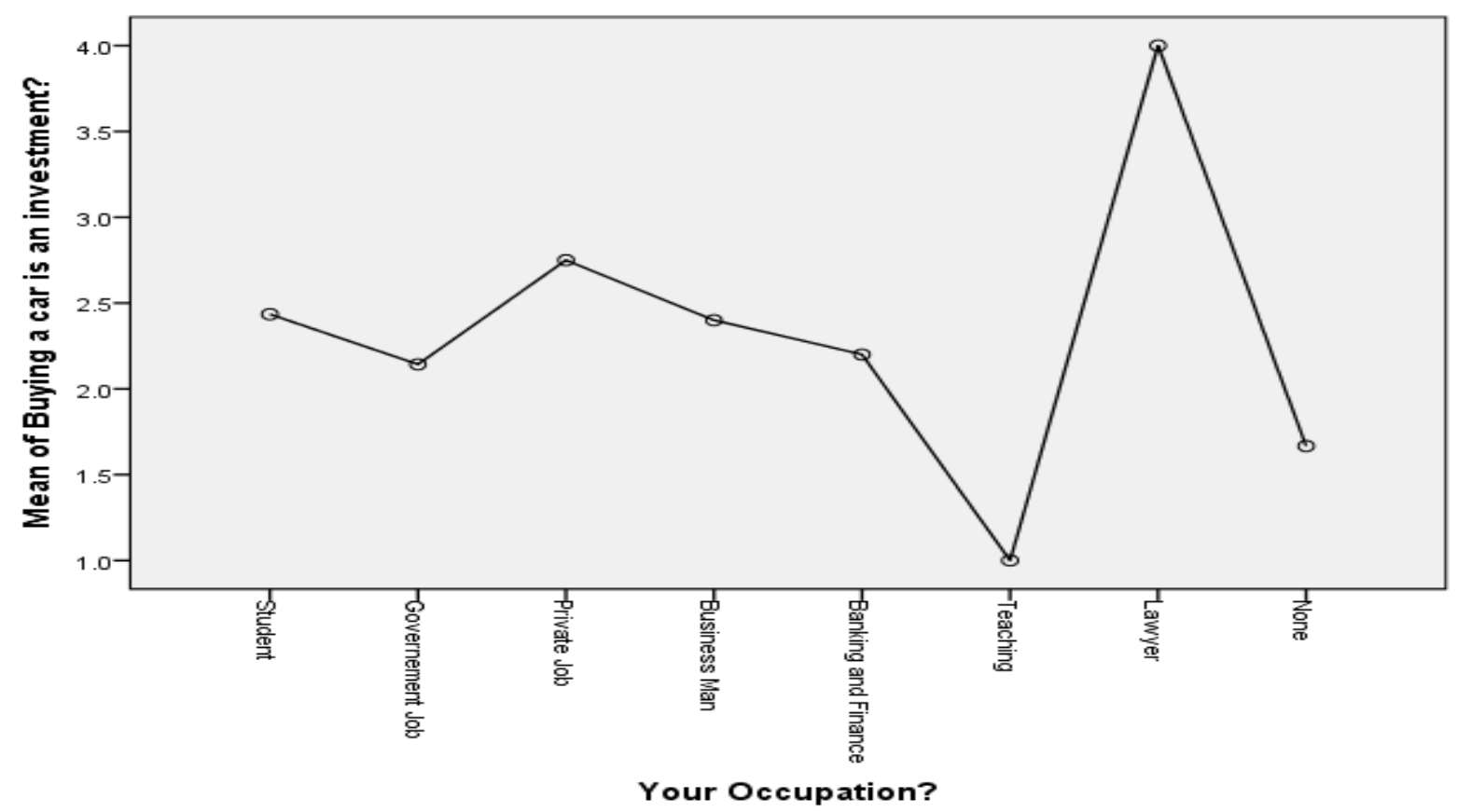

\section{$\underline{\text { Appendix H }}$}

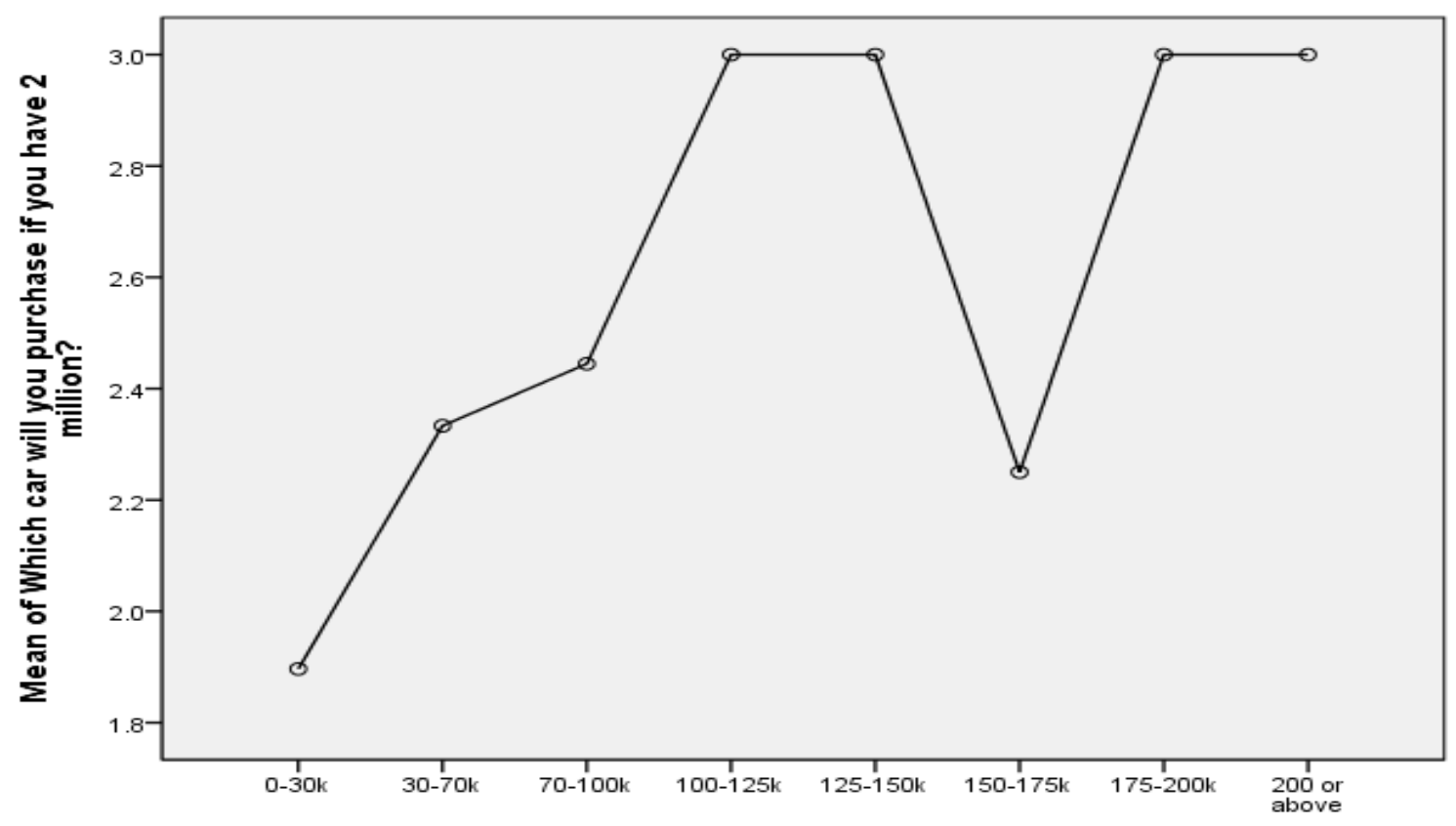
Monthly Income from job or pocket money in case of student? (In 


\begin{tabular}{|c|c|c|c|c|c|c|}
\hline Impact Factor: & $\begin{array}{l}\text { ISRA (India) } \\
\text { ISI (Dubai, UAE } \\
\text { GIF (Australia) } \\
\text { JIF }\end{array}$ & $\begin{array}{l}=1.344 \\
=0.829 \\
=0.564 \\
=1.500\end{array}$ & $\begin{array}{l}\text { SIS (USA) } \\
\text { PИНЦ (Russia) } \\
\text { ESJI (KZ) } \\
\text { SJIF (Morocco) }\end{array}$ & $\begin{array}{l}=0.912 \\
=0.234 \\
=1.042 \\
=\mathbf{2 . 0 3 1}\end{array}$ & $\begin{array}{l}\text { ICV (Poland) } \\
\text { PIF (India) } \\
\text { IBI (India) }\end{array}$ & $\begin{array}{l}=6.630 \\
=1.940 \\
=4.260\end{array}$ \\
\hline
\end{tabular}

\section{Appendix I}

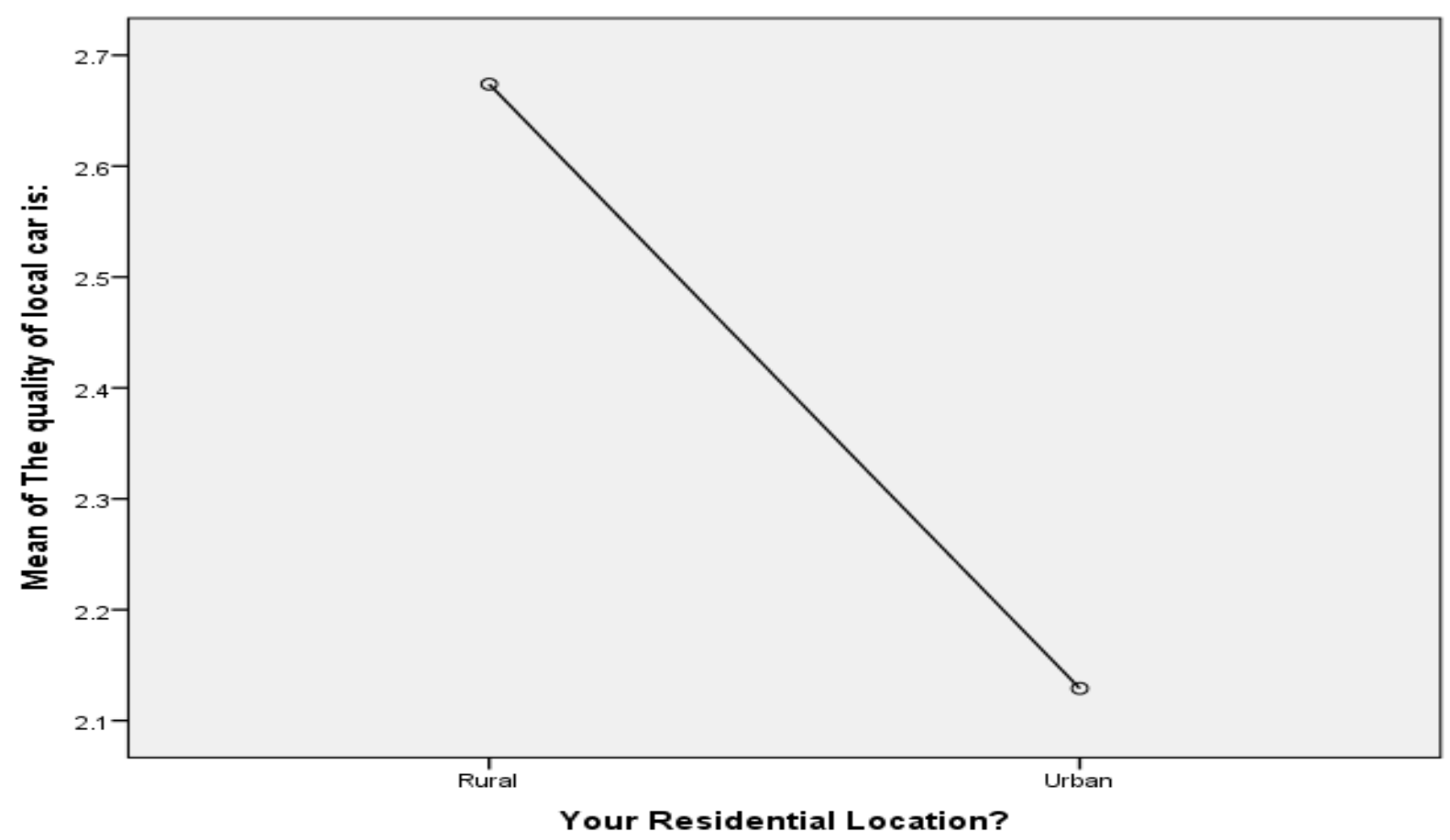

$\underline{\text { Appendix } 1}$

Frequencies

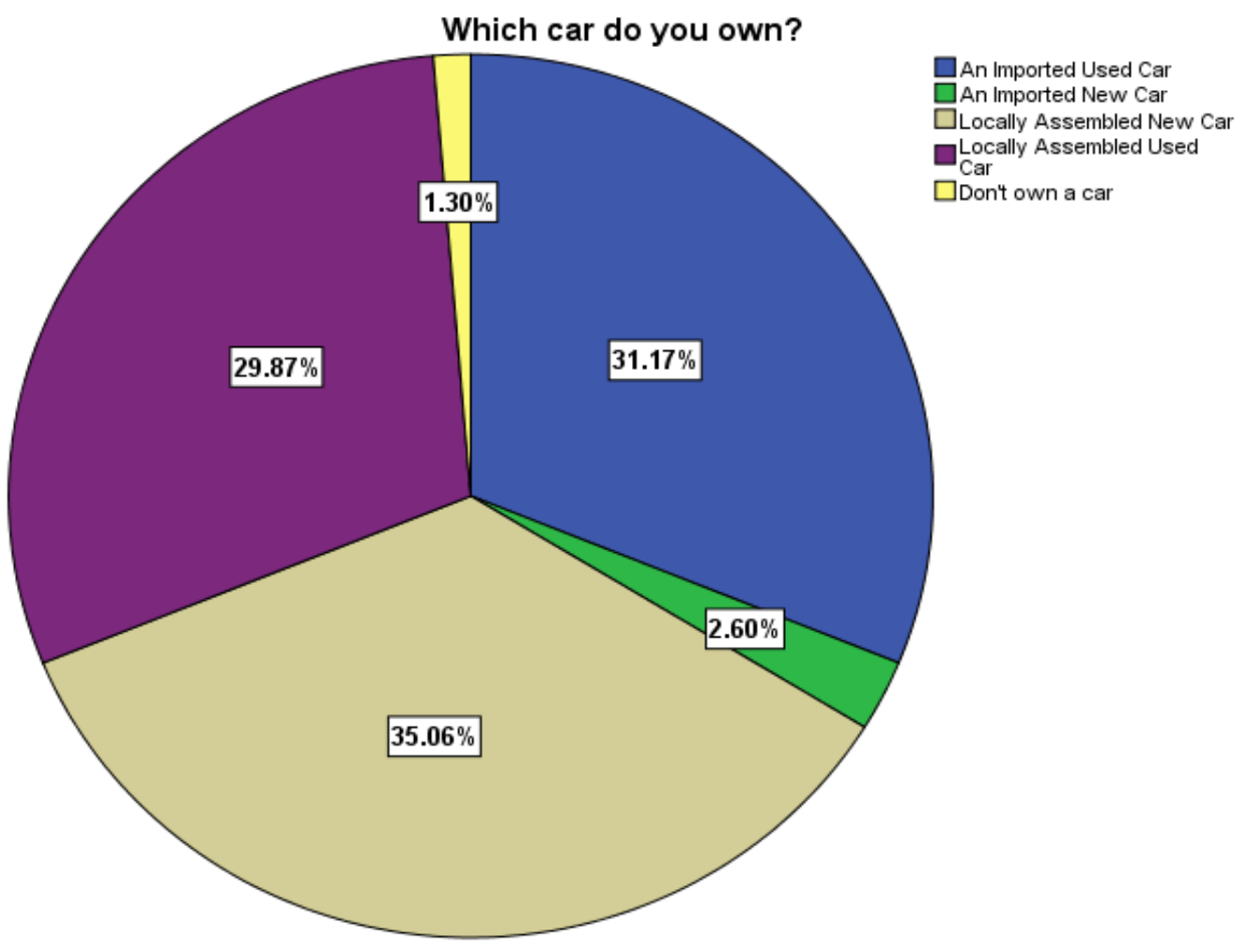




\begin{tabular}{l|lrl|l|ll} 
& ISRA (India) & $=\mathbf{1 . 3 4 4}$ & SIS (USA) & $=\mathbf{0 . 9 1 2}$ & ICV (Poland) & $=\mathbf{6 . 6 3 0}$ \\
Impact Factor: & ISI (Dubai, UAE) $=\mathbf{0 . 8 2 9}$ & PVHIL (Russia) $=\mathbf{0 . 2 3 4}$ & PIF (India) & $=\mathbf{1 . 9 4 0}$ \\
& GIF (Australia) & $\mathbf{0 . 5 6 4}$ & ESJI (KZ) & $=\mathbf{1 . 0 4 2}$ & IBI (India) & $\mathbf{4 . 2 6 0}$
\end{tabular}

\section{Appendix 2}

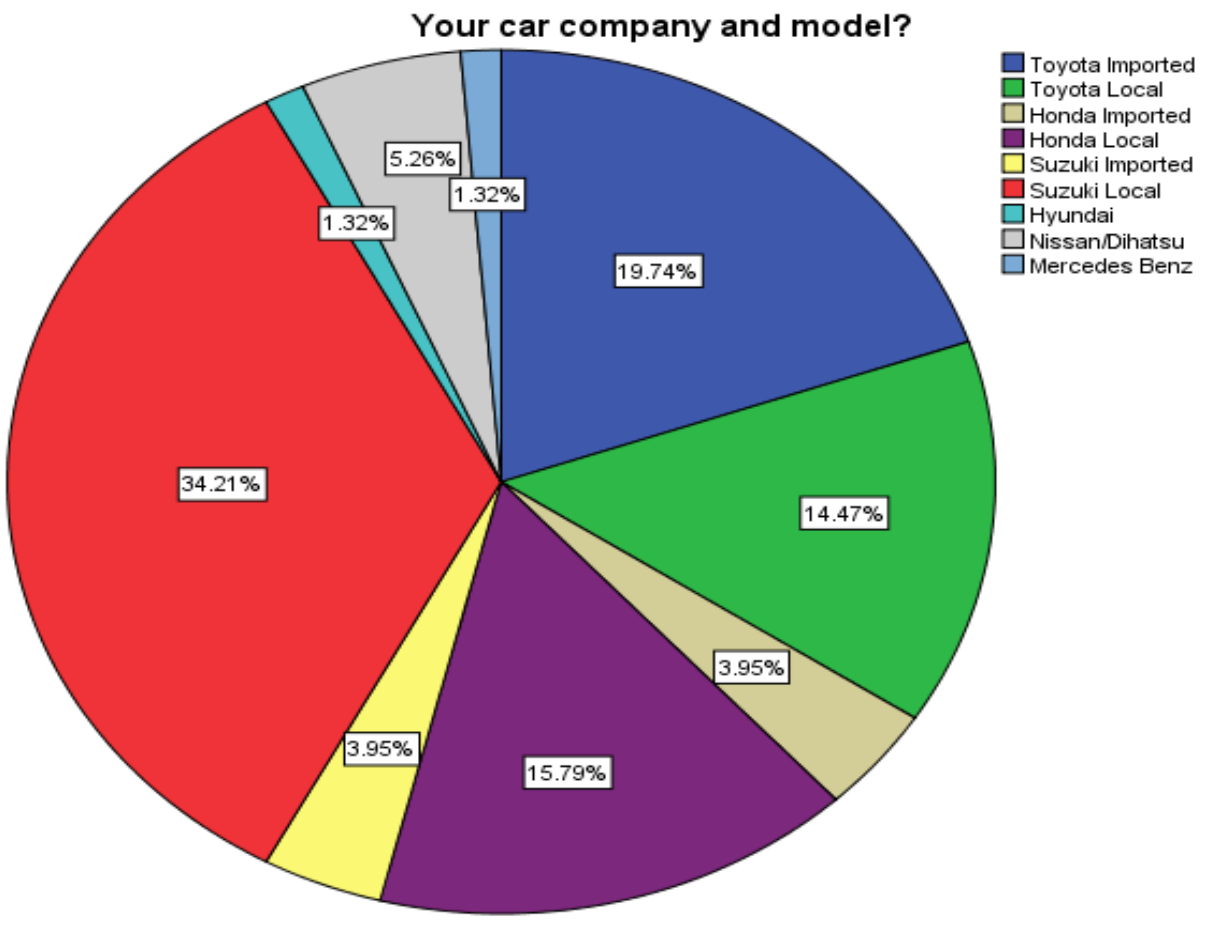

\section{$\underline{\text { Appendix } 3}$}

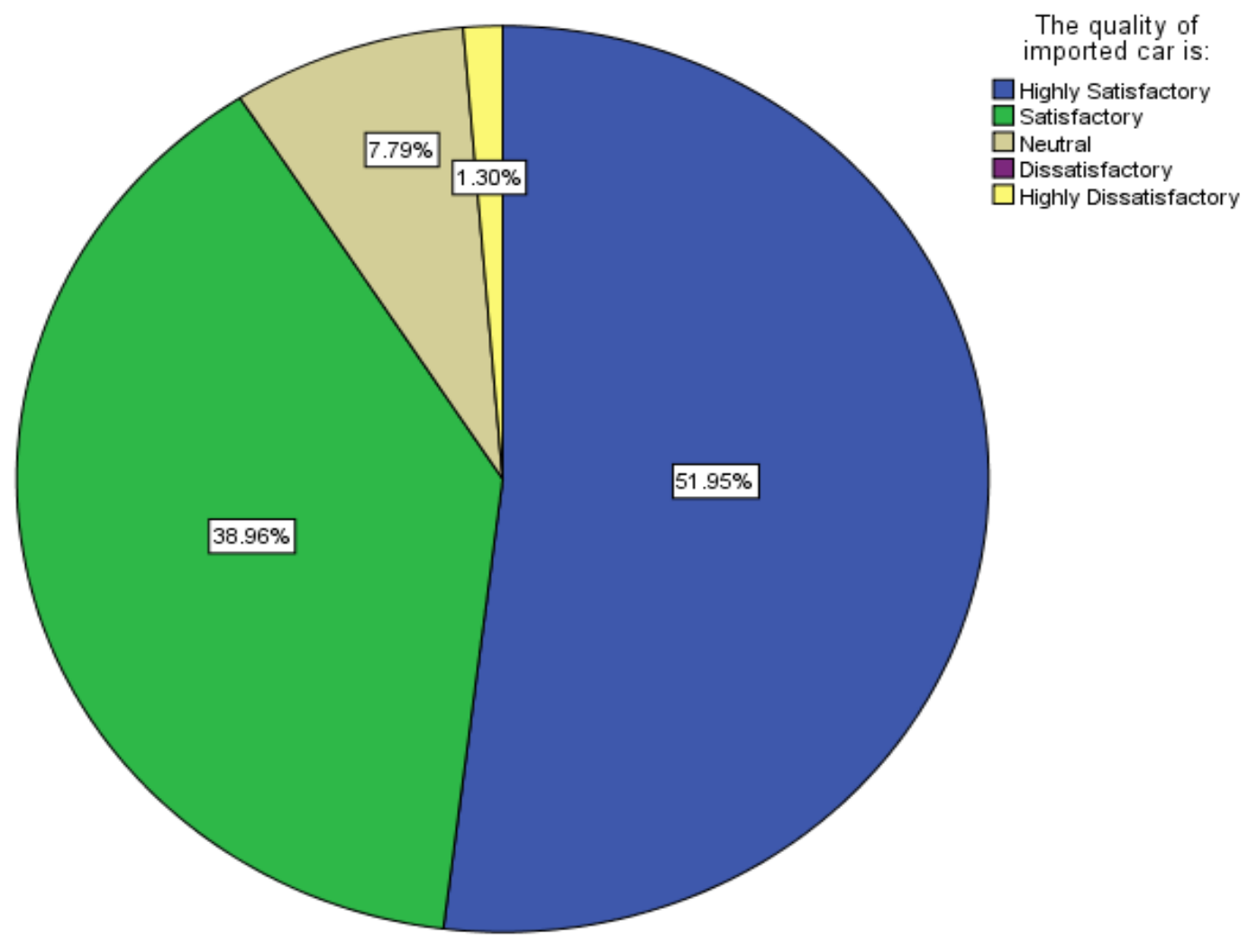




\begin{tabular}{l|lrl|l|ll} 
& ISRA (India) & $=\mathbf{1 . 3 4 4}$ & SIS (USA) & $=\mathbf{0 . 9 1 2}$ & ICV (Poland) & $=\mathbf{6 . 6 3 0}$ \\
Impact Factor: & ISI (Dubai, UAE) $=\mathbf{0 . 8 2 9}$ & PVHIL (Russia) $=\mathbf{0 . 2 3 4}$ & PIF (India) & $=\mathbf{1 . 9 4 0}$ \\
& GIF (Australia) & $\mathbf{0 . 5 6 4}$ & ESJI (KZ) & $=\mathbf{1 . 0 4 2}$ & IBI (India) & $\mathbf{4 . 2 6 0}$
\end{tabular}

\section{Appendix 4}

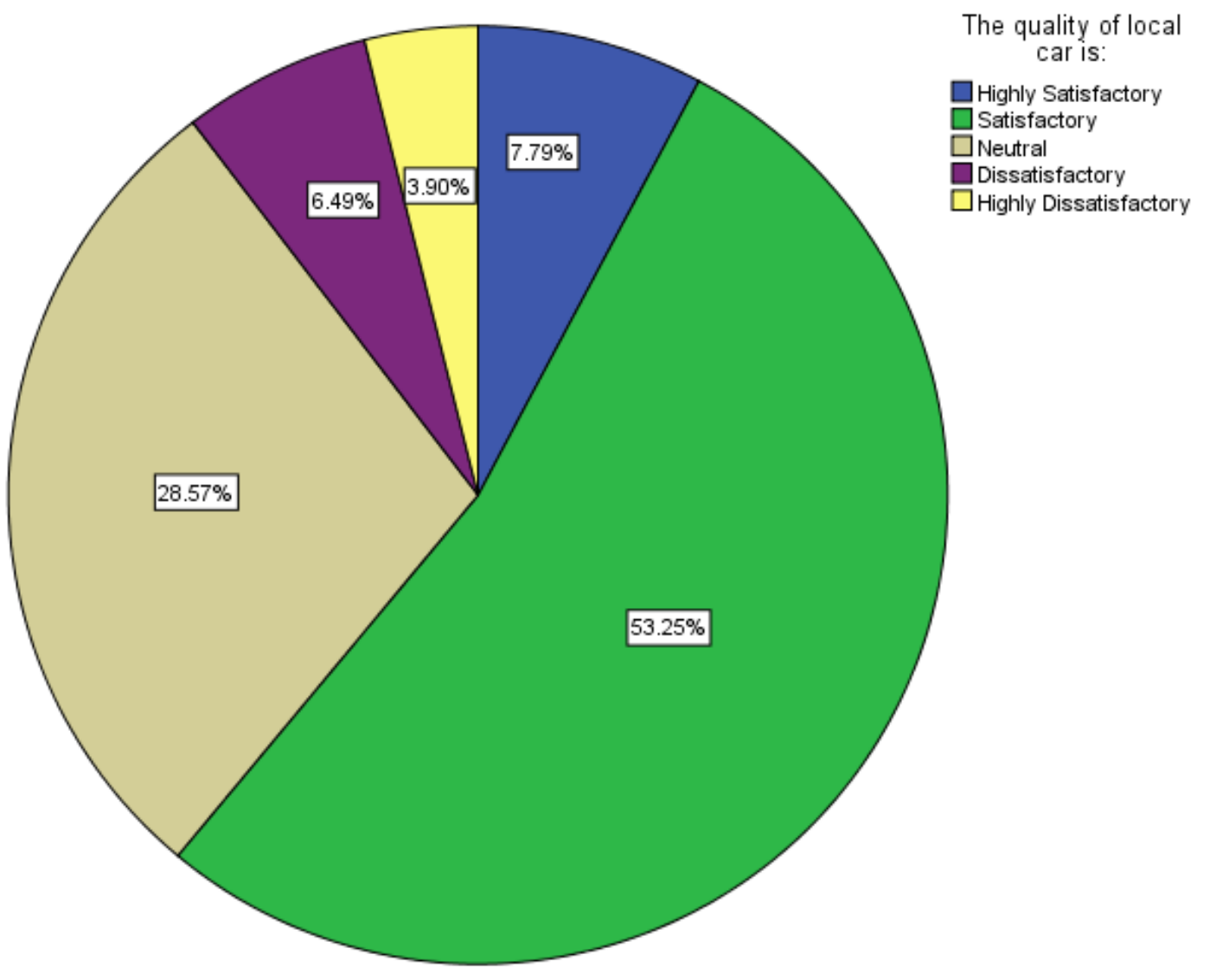

\section{$\underline{\text { Appendix } 5}$}

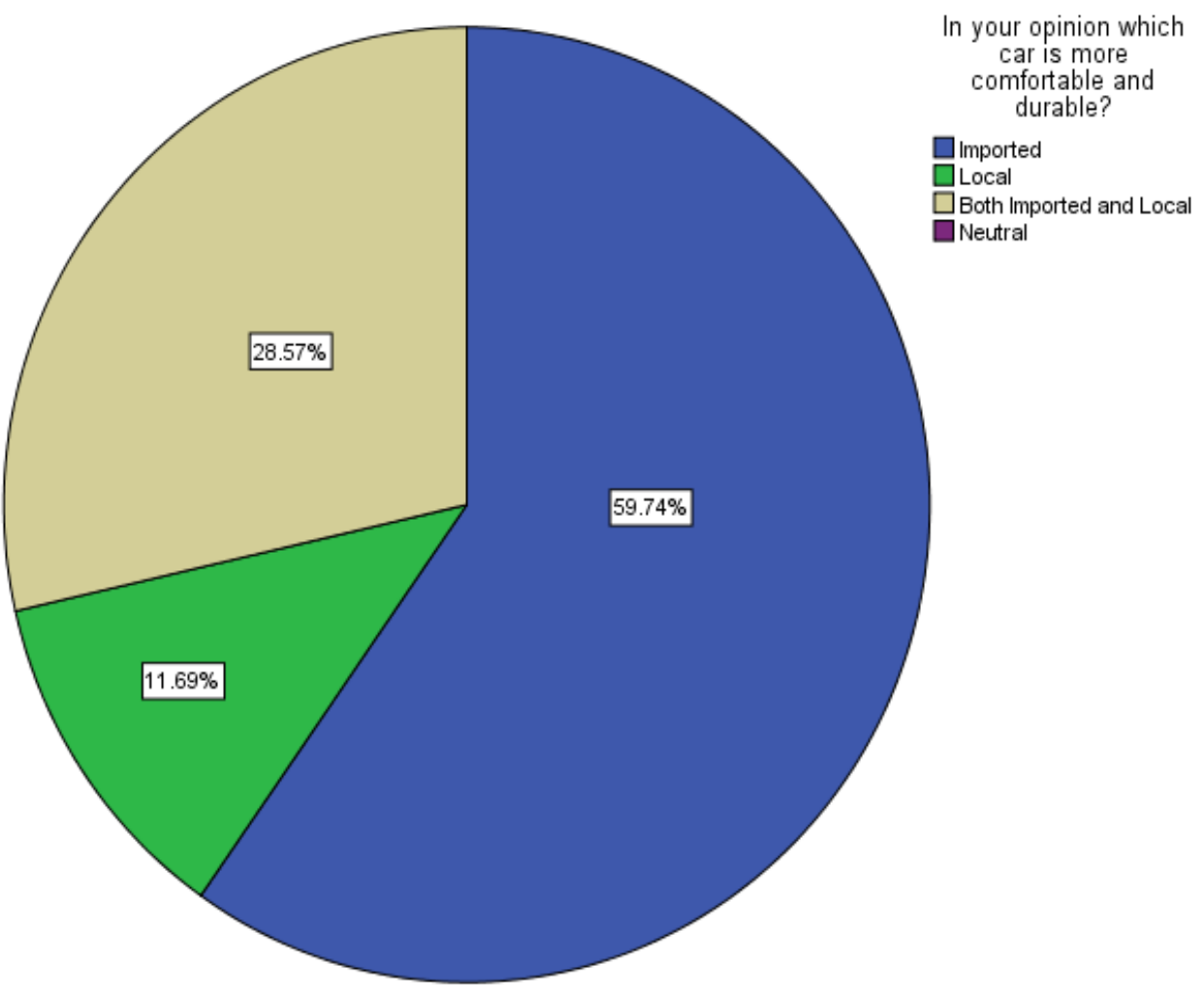




\begin{tabular}{l|lrl|l|ll} 
& ISRA (India) & $=\mathbf{1 . 3 4 4}$ & SIS (USA) & $=\mathbf{0 . 9 1 2}$ & ICV (Poland) & $=\mathbf{6 . 6 3 0}$ \\
Impact Factor: & ISI (Dubai, UAE) $=\mathbf{0 . 8 2 9}$ & PVHIL (Russia) $=\mathbf{0 . 2 3 4}$ & PIF (India) & $=\mathbf{1 . 9 4 0}$ \\
& GIF (Australia) & $\mathbf{0 . 5 6 4}$ & ESJI (KZ) & $=\mathbf{1 . 0 4 2}$ & IBI (India) & $\mathbf{4 . 2 6 0}$
\end{tabular}

\section{$\underline{\text { Appendix } 6}$}

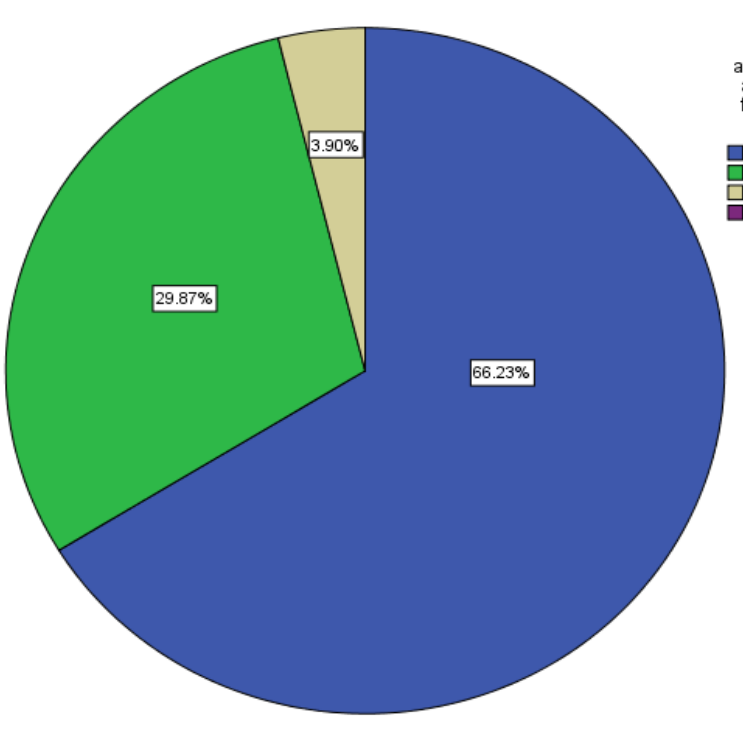

To what

extent you

are conscious
about safety

features in a

To great extent

$\square$ Neutral

Not Conscious

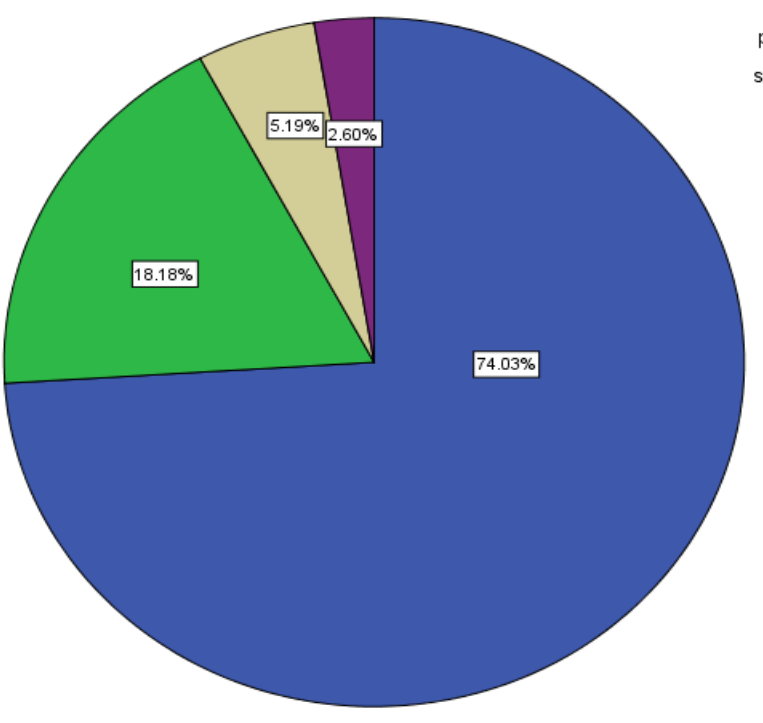

What is your

the following

safety features?
(ABS)

1st Priority

2nd Priority

3rd Priority

4th Priority

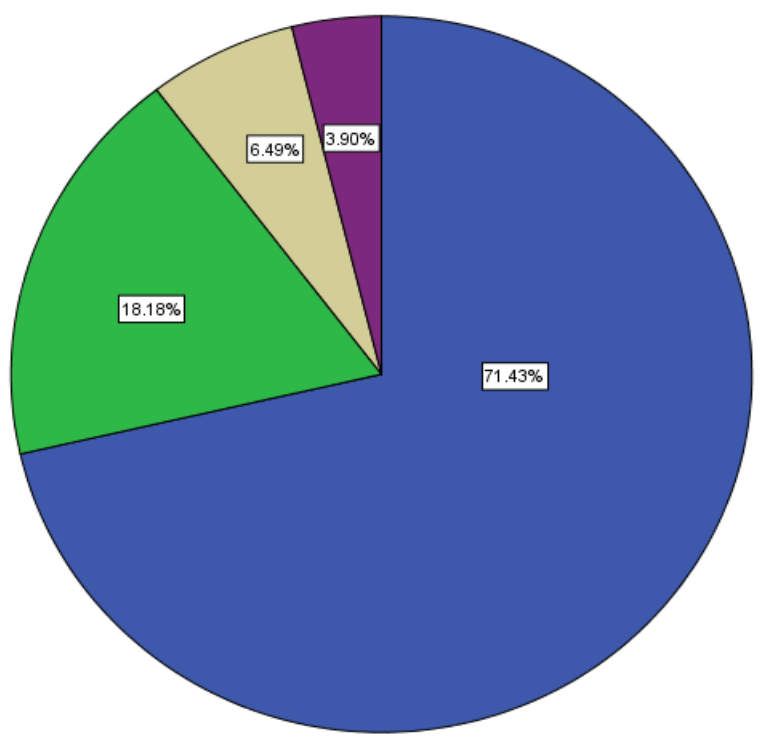

What is your priority level for
the following afety features? (AirBag)

口ist Priority

4th Priority 


\begin{tabular}{l|lrl|l|ll} 
& ISRA (India) & $=\mathbf{1 . 3 4 4}$ & SIS (USA) & $=\mathbf{0 . 9 1 2}$ & ICV (Poland) & $=\mathbf{6 . 6 3 0}$ \\
Impact Factor: & ISI (Dubai, UAE) $=\mathbf{0 . 8 2 9}$ & PUHU (Russia) $=\mathbf{0 . 2 3 4}$ & PIF (India) & $=\mathbf{1 . 9 4 0}$ \\
& GIF (Australia) & $\mathbf{0 . 5 6 4}$ & ESJI (KZ) & $=\mathbf{1 . 0 4 2}$ & IBI (India) & $\mathbf{4 . 2 6 0}$
\end{tabular}

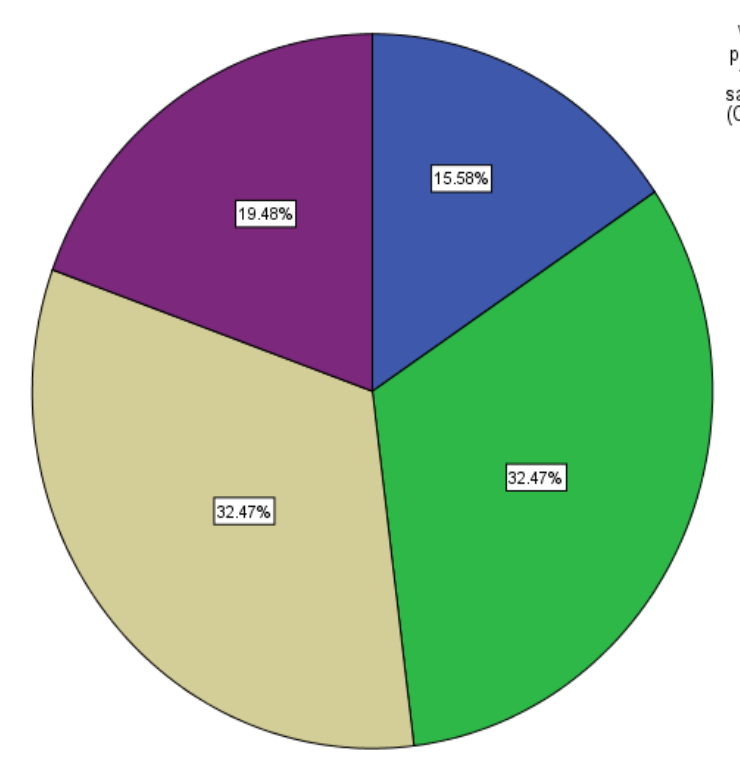

What is your

safety features?

Cruise Control

口1st Priority

$\square$ 4th Priority

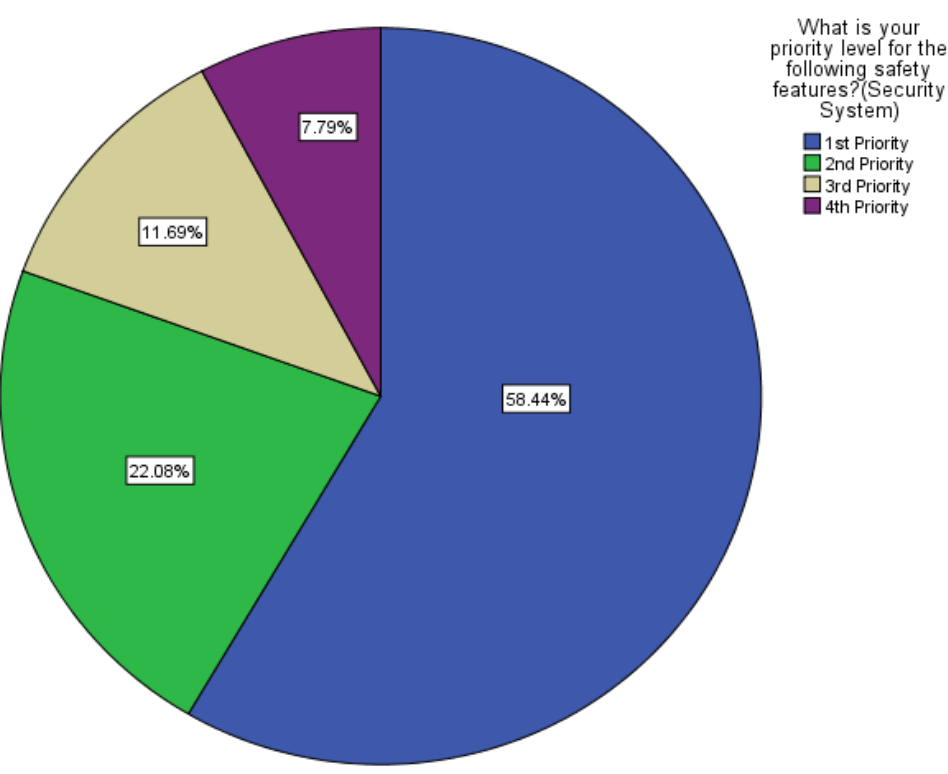




\begin{tabular}{l|lrl|l|ll} 
& ISRA (India) & $=\mathbf{1 . 3 4 4}$ & SIS (USA) & $=\mathbf{0 . 9 1 2}$ & ICV (Poland) & $=\mathbf{6 . 6 3 0}$ \\
Impact Factor: & ISI (Dubai, UAE) $=\mathbf{0 . 8 2 9}$ & PVHIL (Russia) $=\mathbf{0 . 2 3 4}$ & PIF (India) & $=\mathbf{1 . 9 4 0}$ \\
& GIF (Australia) & $\mathbf{0 . 5 6 4}$ & ESJI (KZ) & $=\mathbf{1 . 0 4 2}$ & IBI (India) & $\mathbf{4 . 2 6 0}$
\end{tabular}

\section{Appendix 7}

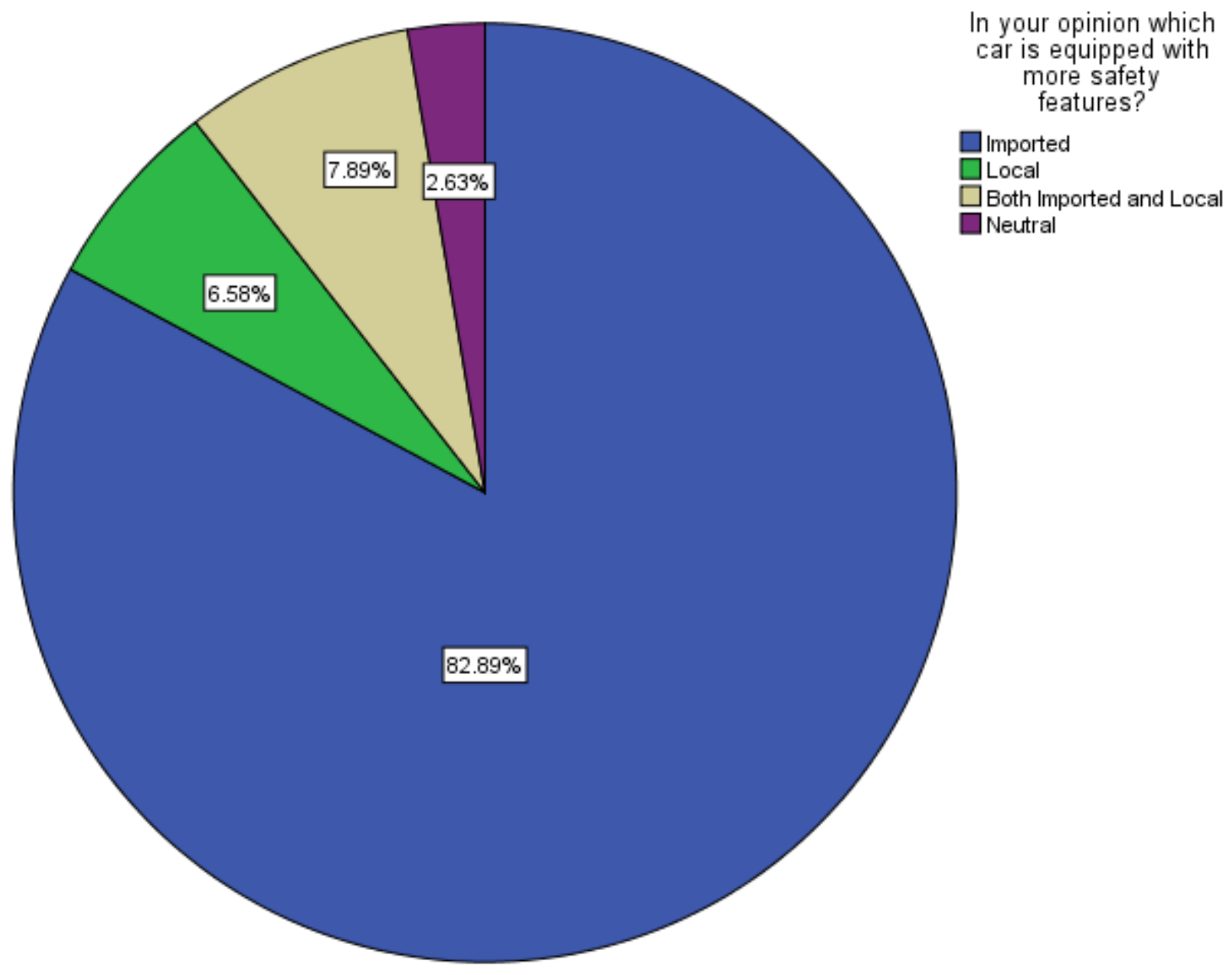

\section{$\underline{\text { Appendix } 8}$}

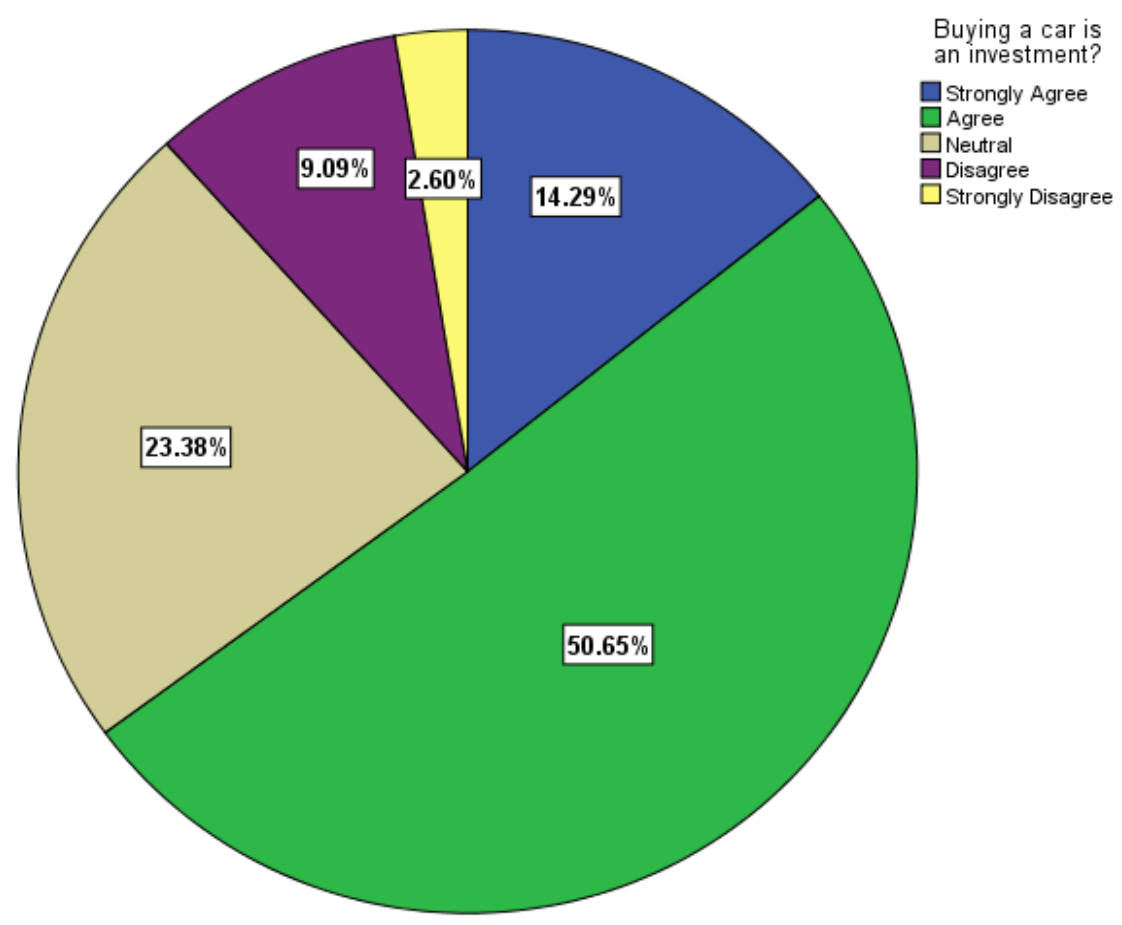




\begin{tabular}{l|lrl|l|ll} 
& ISRA (India) & $=\mathbf{1 . 3 4 4}$ & SIS (USA) & $=\mathbf{0 . 9 1 2}$ & ICV (Poland) & $=\mathbf{6 . 6 3 0}$ \\
Impact Factor: & ISI (Dubai, UAE) $=\mathbf{0 . 8 2 9}$ & PUHU (Russia) $=\mathbf{0 . 2 3 4}$ & PIF (India) & $=\mathbf{1 . 9 4 0}$ \\
& GIF (Australia) & $\mathbf{0 . 5 6 4}$ & ESJI (KZ) & $=\mathbf{1 . 0 4 2}$ & IBI (India) & $\mathbf{4 . 2 6 0}$
\end{tabular}
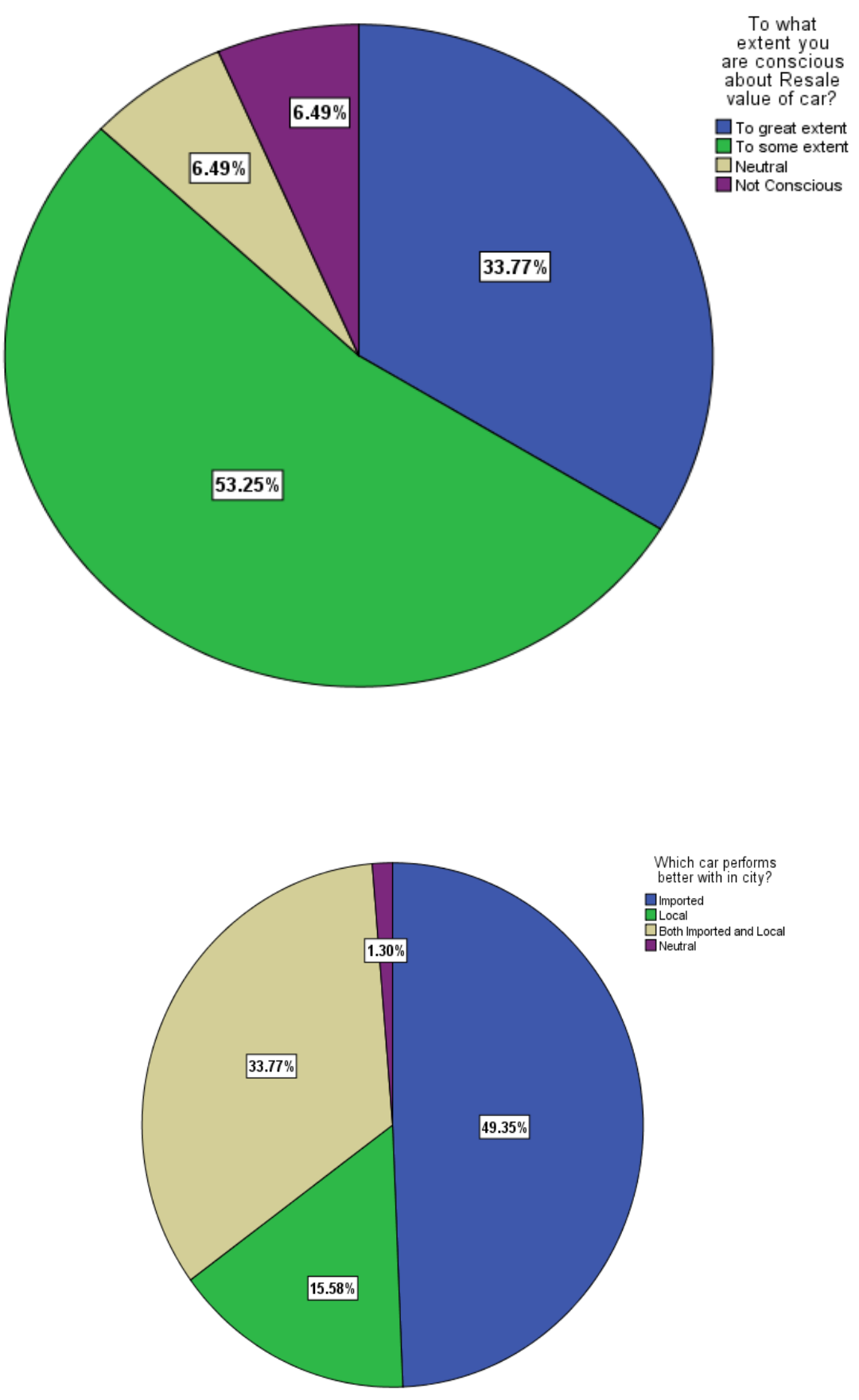


\begin{tabular}{l|lrl|l|ll} 
& ISRA (India) & $=\mathbf{1 . 3 4 4}$ & SIS (USA) & $=\mathbf{0 . 9 1 2}$ & ICV (Poland) & $=\mathbf{6 . 6 3 0}$ \\
Impact Factor: & ISI (Dubai, UAE) $=\mathbf{0 . 8 2 9}$ & PVHIL (Russia) $=\mathbf{0 . 2 3 4}$ & PIF (India) & $=\mathbf{1 . 9 4 0}$ \\
& GIF (Australia) & $\mathbf{0 . 5 6 4}$ & ESJI (KZ) & $=\mathbf{1 . 0 4 2}$ & IBI (India) & $\mathbf{4 . 2 6 0}$
\end{tabular}

\section{Appendix 9}
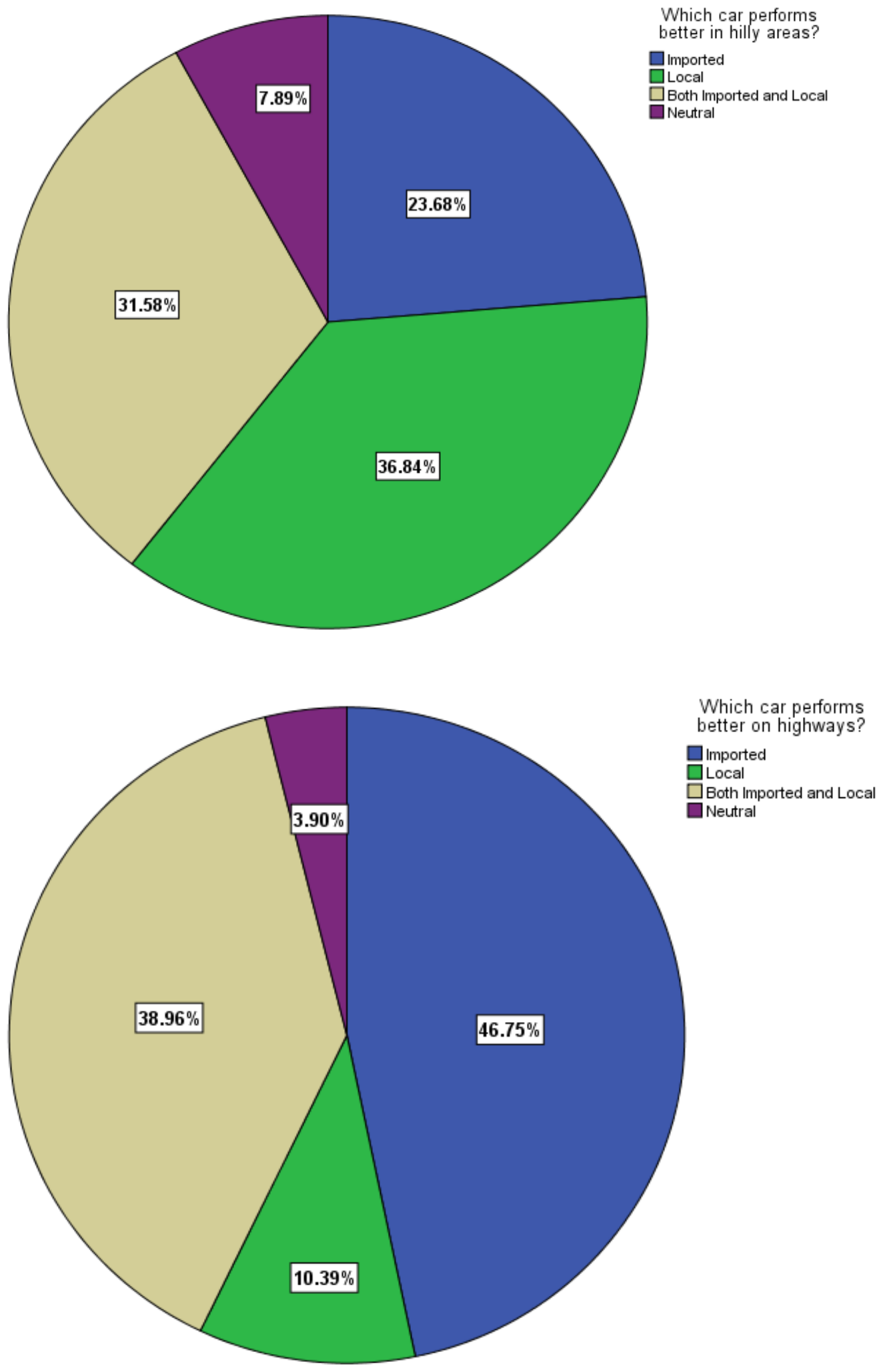


\begin{tabular}{l|lr|ll|ll} 
& ISRA (India) & $=\mathbf{1 . 3 4 4}$ & SIS (USA) & $=\mathbf{0 . 9 1 2}$ & ICV (Poland) & $=\mathbf{6 . 6 3 0}$ \\
Impact Factor: & ISI (Dubai, UAE) $=\mathbf{0 . 8 2 9}$ & PUHI (Russia) & $=\mathbf{0 . 2 3 4}$ & PIF (India) & $=\mathbf{1 . 9 4 0}$ \\
& GIF (Australia) & $=\mathbf{0 . 5 6 4}$ & ESJI (KZ) & $=\mathbf{1 . 0 4 2}$ & IBI (India) & $\mathbf{4 . 2 6 0}$ \\
& JIF & $\mathbf{1 . 5 0 0}$ & SJIF (Morocco) & $\mathbf{2 . 0 3 1}$ & & \\
\hline
\end{tabular}

\section{Appendix 10}
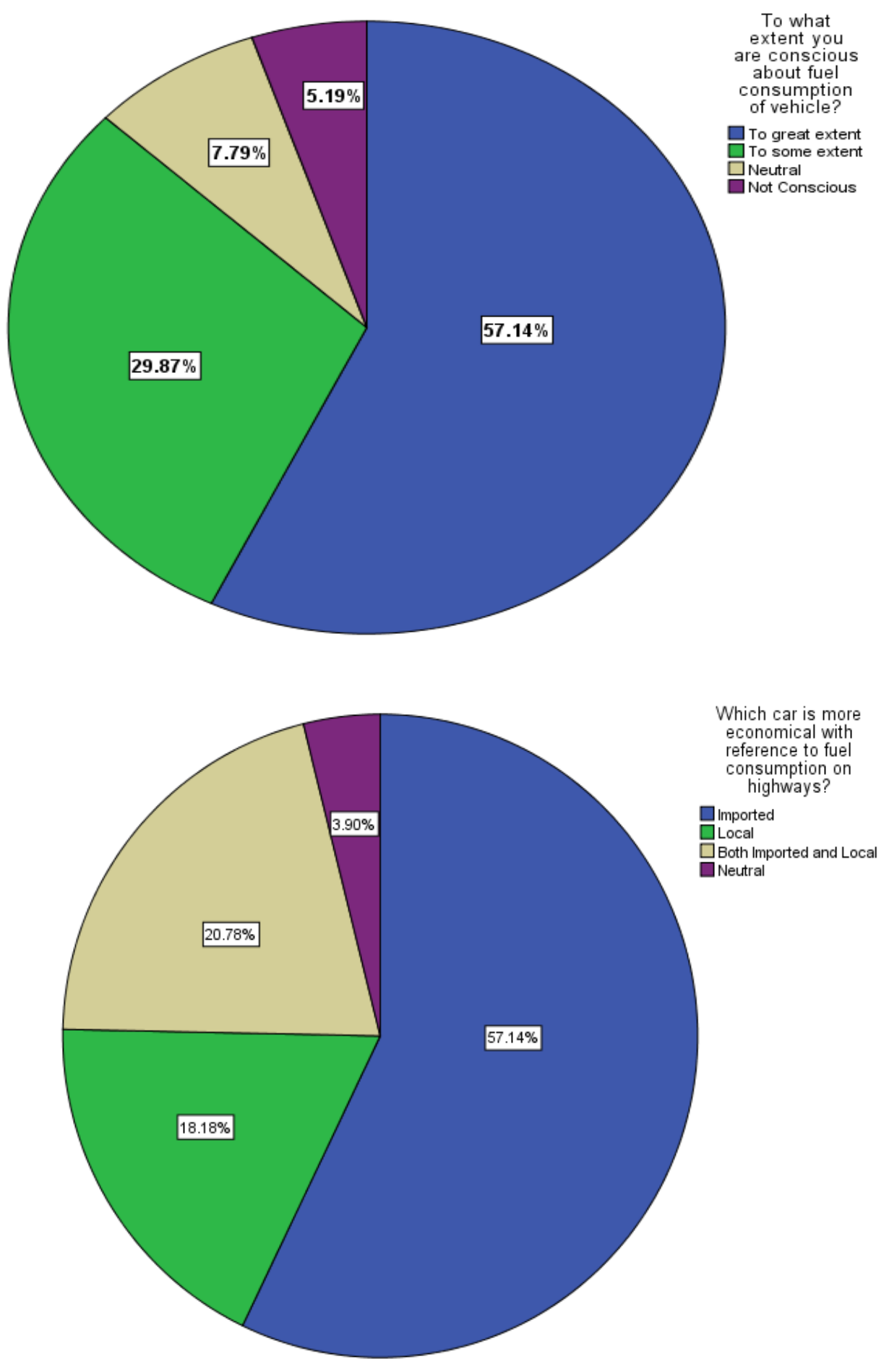


\begin{tabular}{l|lrl|l|ll} 
& ISRA (India) & $=\mathbf{1 . 3 4 4}$ & SIS (USA) & $=\mathbf{0 . 9 1 2}$ & ICV (Poland) & $=\mathbf{6 . 6 3 0}$ \\
Impact Factor: & ISI (Dubai, UAE) $=\mathbf{0 . 8 2 9}$ & PUHL (Russia) $=\mathbf{0 . 2 3 4}$ & PIF (India) & $=\mathbf{1 . 9 4 0}$ \\
& GIF (Australia) & $\mathbf{0 . 5 6 4}$ & ESJI (KZ) & $=\mathbf{1 . 0 4 2}$ & IBI (India) & $=\mathbf{4 . 2 6 0}$ \\
& JIF & $\mathbf{1 . 5 0 0}$ & SJIF (Morocco) & $=\mathbf{2 . 0 3 1}$ & & \\
\hline
\end{tabular}

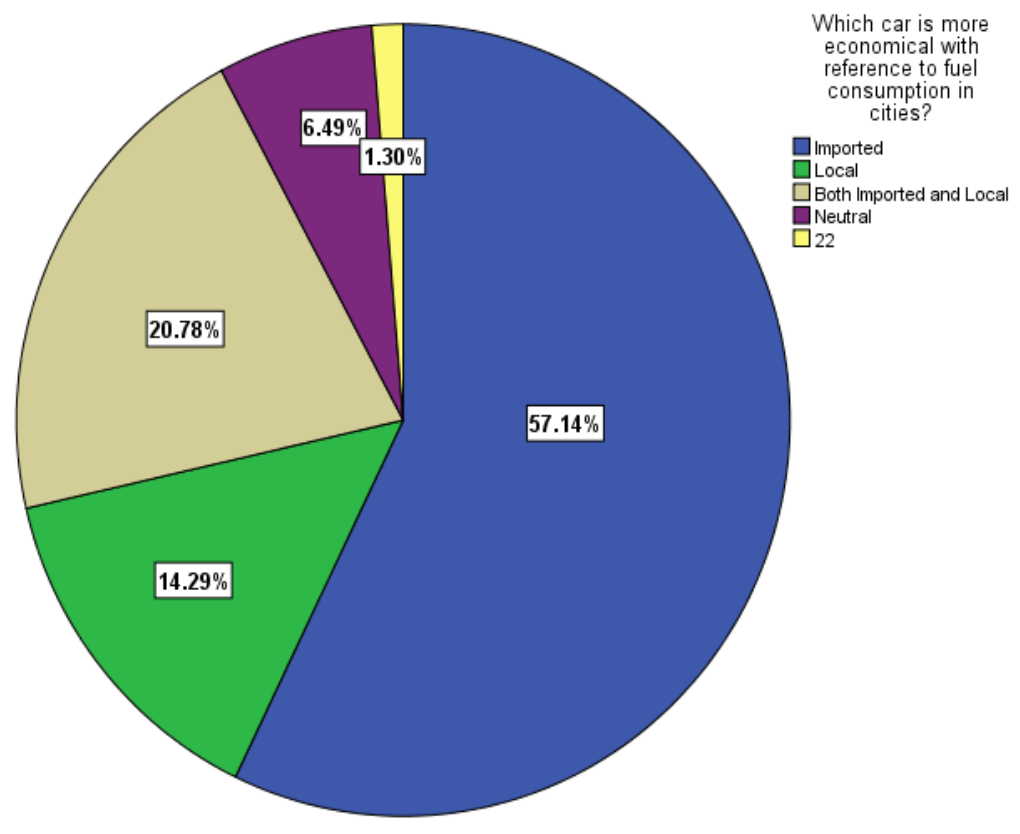




\begin{tabular}{l|lr|ll|ll} 
& ISRA (India) & $=\mathbf{1 . 3 4 4}$ & SIS (USA) & $=\mathbf{0 . 9 1 2}$ & ICV (Poland) & $=\mathbf{6 . 6 3 0}$ \\
Impact Factor: & ISI (Dubai, UAE) $=\mathbf{0 . 8 2 9}$ & PUHI (Russia) & $=\mathbf{0 . 2 3 4}$ & PIF (India) & $=\mathbf{1 . 9 4 0}$ \\
& GIF (Australia) & $=\mathbf{0 . 5 6 4}$ & ESJI (KZ) & $=\mathbf{1 . 0 4 2}$ & IBI (India) & $\mathbf{4 . 2 6 0}$ \\
& JIF & $\mathbf{1 . 5 0 0}$ & SJIF (Morocco) & $\mathbf{2 . 0 3 1}$ & & \\
\hline
\end{tabular}

\section{Appendix 11}

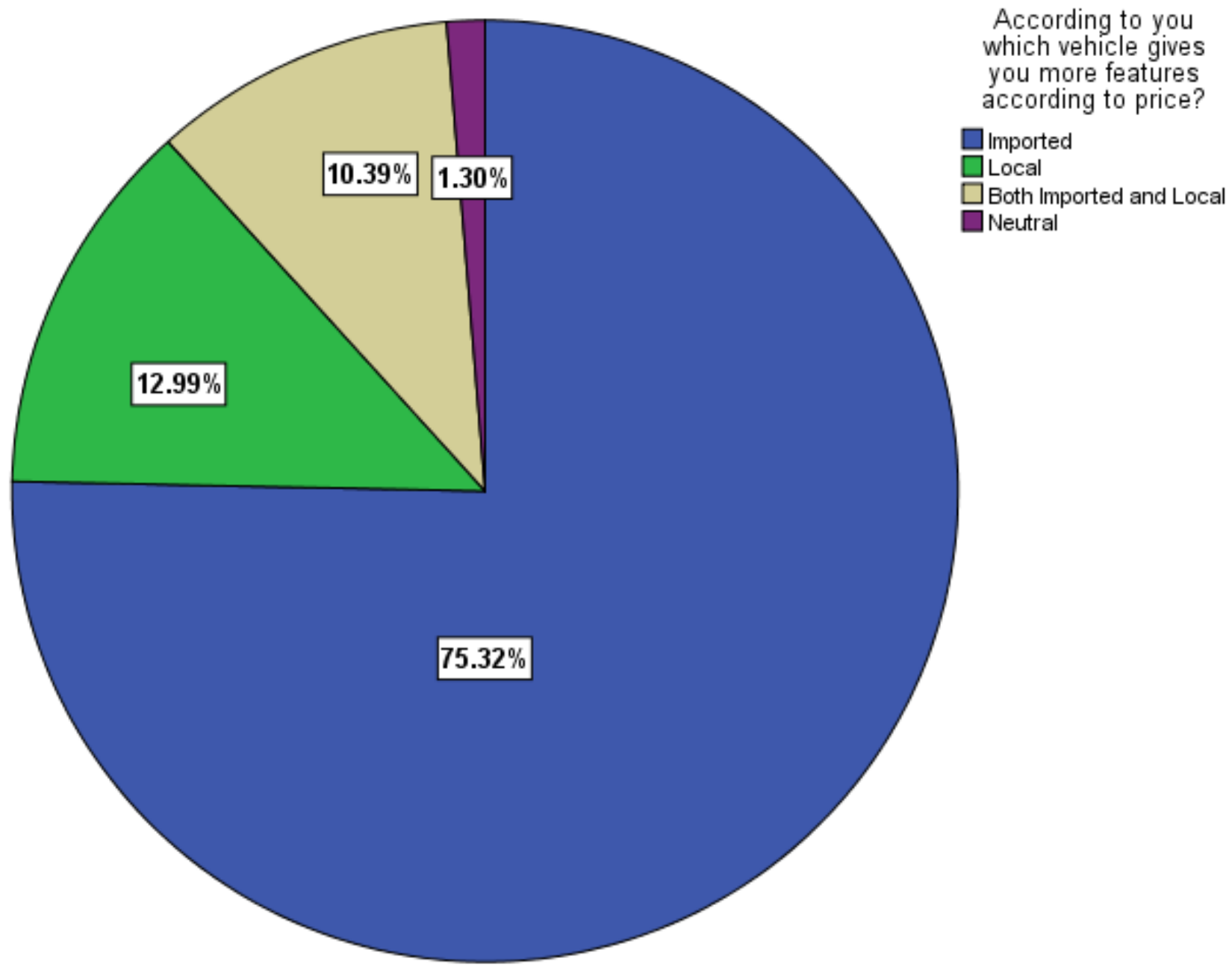

\section{$\underline{\text { Appendix } 12}$}

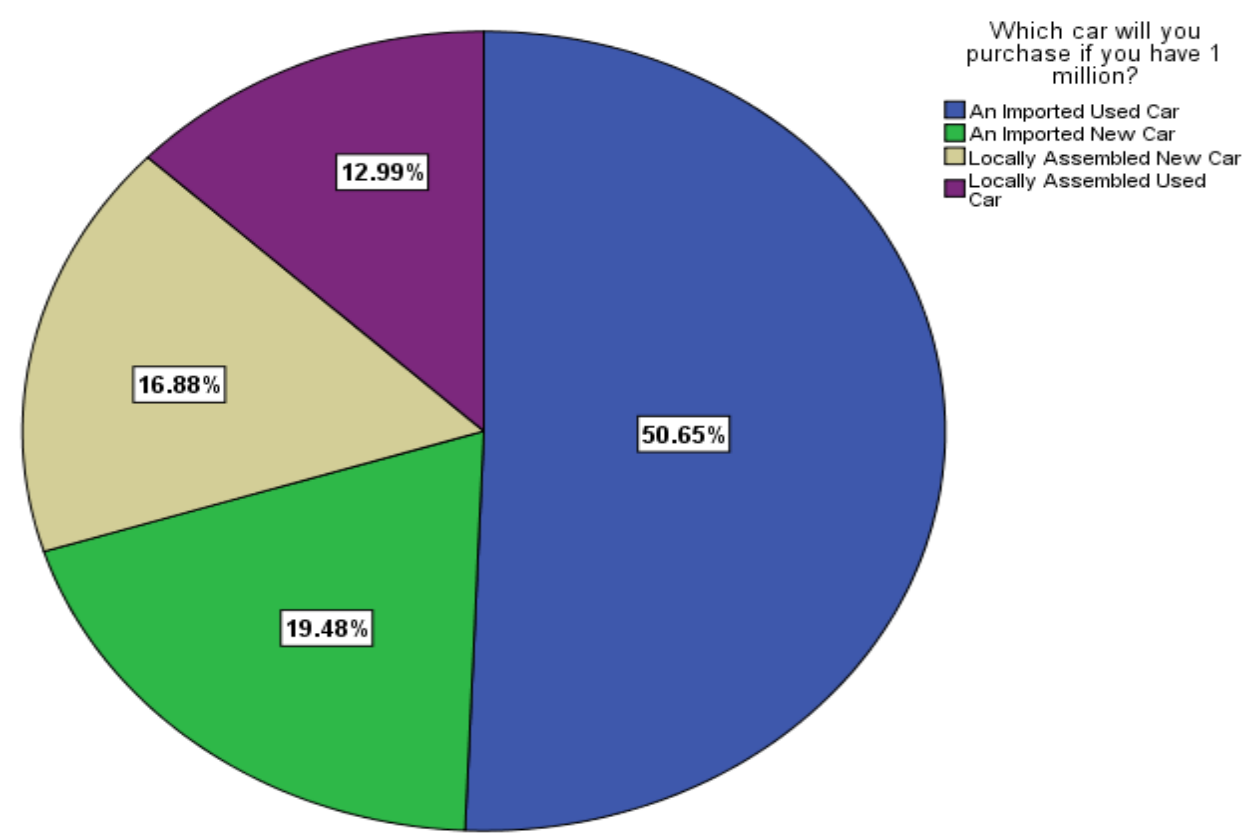




\begin{tabular}{l|lrl|l|ll} 
& ISRA (India) & $=\mathbf{1 . 3 4 4}$ & SIS (USA) & $=\mathbf{0 . 9 1 2}$ & ICV (Poland) & $=\mathbf{6 . 6 3 0}$ \\
Impact Factor: & ISI (Dubai, UAE) $=\mathbf{0 . 8 2 9}$ & PUHU (Russia) $=\mathbf{0 . 2 3 4}$ & PIF (India) & $=\mathbf{1 . 9 4 0}$ \\
& GIF (Australia) & $\mathbf{0 . 5 6 4}$ & ESJI (KZ) & $=\mathbf{1 . 0 4 2}$ & IBI (India) & $\mathbf{4 . 2 6 0}$
\end{tabular}
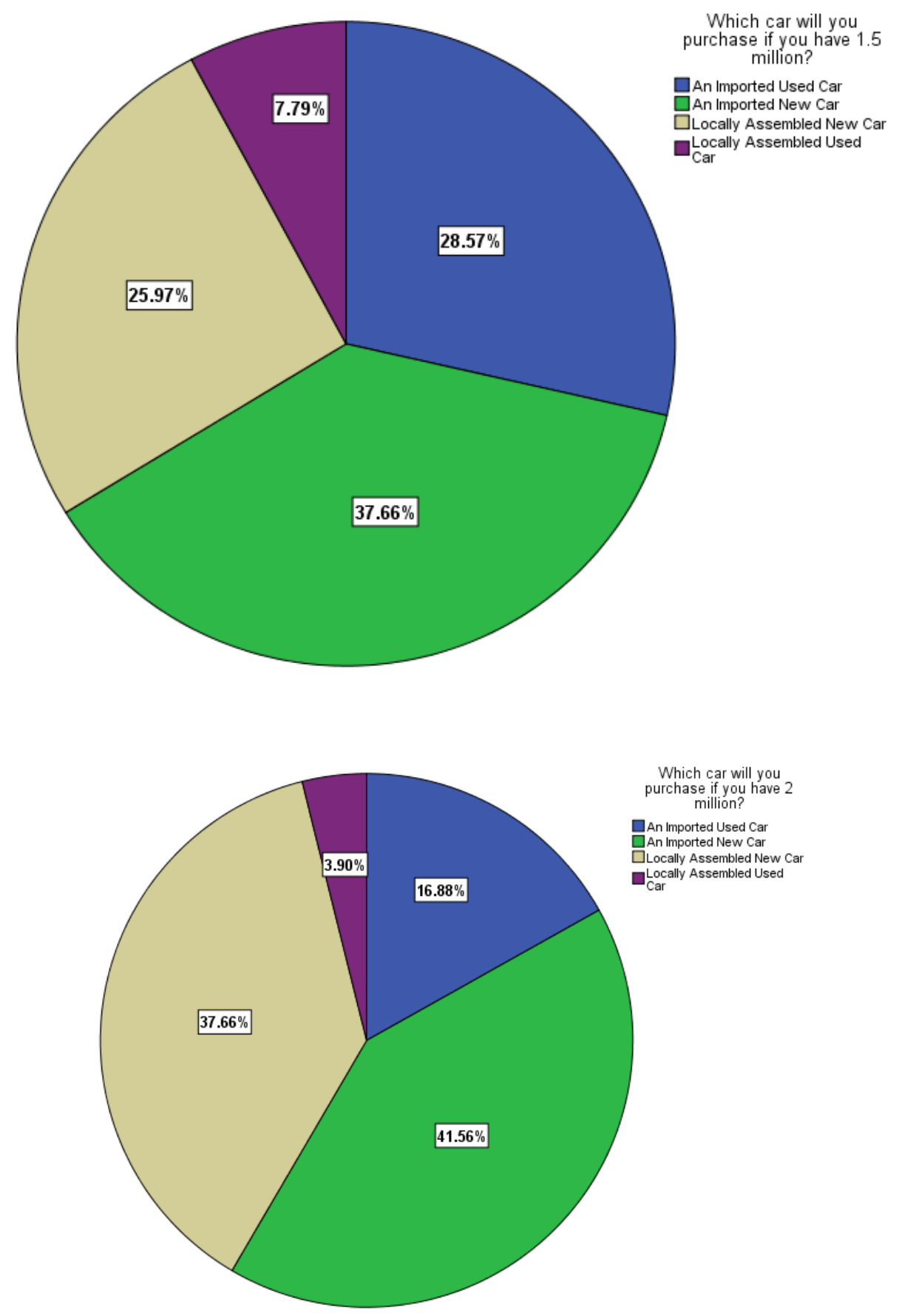


\begin{tabular}{l|lrl|l|ll} 
& ISRA (India) & $=\mathbf{1 . 3 4 4}$ & SIS (USA) & $=\mathbf{0 . 9 1 2}$ & ICV (Poland) & $=\mathbf{6 . 6 3 0}$ \\
Impact Factor: & ISI (Dubai, UAE) $=\mathbf{0 . 8 2 9}$ & PUHL (Russia) $=\mathbf{0 . 2 3 4}$ & PIF (India) & $=1.940$ \\
& GIF (Australia) & $\mathbf{0 . 5 6 4}$ & ESJI (KZ) & $=\mathbf{1 . 0 4 2}$ & IBI (India) & $=\mathbf{4 . 2 6 0}$ \\
& JIF & $\mathbf{1 . 5 0 0}$ & SJIF (Morocco) & $=\mathbf{2 . 0 3 1}$ & & \\
\hline
\end{tabular}

\section{Appendix 13 Questionnaire}

\section{Factors Influencing the Likeness of Imported and Local Cars}

1. Age

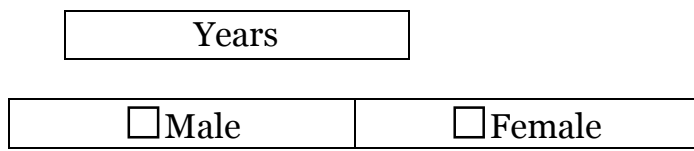

2. Gender

3. Marital

Status?

\begin{tabular}{|c|c|c|c|}
\hline$\square$ Single & $\square$ Married & $\square$ Divorced & $\square$ Widow \\
\hline
\end{tabular}

4. Type of family system in which you are living?

\begin{tabular}{|l|l|}
\hline$\square$ Nuclear & $\square$ Joint \\
\hline
\end{tabular}

5. Number of family members?

6. Your education?

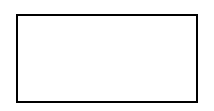

\begin{tabular}{|l|l|l|l|l|l|l|}
\hline$\square$ Uneducated & $\square$ Primary & $\square$ Middle & $\square$ Matric & $\square$ Intermediate & $\square$ Graduate & $\begin{array}{c}\square \text { Post } \\
\text { Graduate or } \\
\text { above }\end{array}$ \\
\hline
\end{tabular}

7. Your Employment status:

\begin{tabular}{|c|c|c|}
\hline $\begin{array}{c}\square \text { Employ } \\
\text { ed }\end{array}$ & $\begin{array}{c}\square \text { Self- } \\
\text { Employed }\end{array}$ & $\square$ Unemployed \\
\hline
\end{tabular}

8. Your Occupation:

9. Your Monthly Income from Job/Business or Pocket Money in case of student? (In Thousands)

\begin{tabular}{|c|c|c|c|c|c|c|c|}
\hline o-3ok & $30-70 \mathrm{k}$ & $70-100 \mathrm{k}$ & $100-125 \mathrm{k}$ & $125-15 \mathrm{ok}$ & $150-175 \mathrm{k}$ & $175-200 \mathrm{k}$ & $\begin{array}{c}200 \text { or } \\
\text { above }\end{array}$ \\
\hline
\end{tabular}

10. Your residential

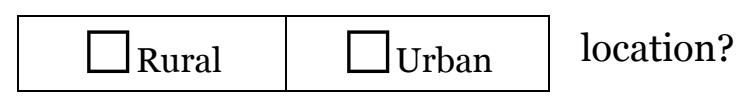

11. Which car do you own? New car
$\square$ An Imported Used car
An Imported New car
Locally assembled
Locally assembled Used car
Don't own a car

12. Your Car Company and Model?

\begin{tabular}{|l|c|c|}
\hline Company Name & Model Name & Year \\
\hline & & \\
\hline
\end{tabular}

13. The car you own is: 


\begin{tabular}{l|lr|ll|ll} 
& ISRA (India) & $=\mathbf{1 . 3 4 4}$ & SIS (USA) & $=\mathbf{0 . 9 1 2}$ & ICV (Poland) & $=\mathbf{6 . 6 3 0}$ \\
Impact Factor: & ISI (Dubai, UAE) $=\mathbf{0 . 8 2 9}$ & PUHIL (Russia) $=\mathbf{0 . 2 3 4}$ & PIF (India) & $=\mathbf{1 . 9 4 0}$ \\
& GIF (Australia) & $\mathbf{0 . 5 6 4}$ & ESJI (KZ) & $=\mathbf{1 . 0 4 2}$ & IBI (India) & $\mathbf{= 4 . 2 6 0}$ \\
& JIF & $=\mathbf{1 . 5 0 0}$ & SJIF (Morocco) & $=\mathbf{2 . 0 3 1}$ & & \\
\hline
\end{tabular}

\section{$\square$ Given by Parents $\square$ Self Purchased $\square$ Leased}

Other

14. For what purposes you use your car on daily basis, tell us in percentage out of $100 \%$ ?

\begin{tabular}{|l|l|l|l|l|}
\hline $\begin{array}{l}\text { For Office } \\
\text { purpose }\end{array}$ & For Shopping & $\begin{array}{l}\text { For Outing/ } \\
\text { Trips }\end{array}$ & For Rent & $\begin{array}{l}\text { For Family } \\
\text { use }\end{array}$ \\
\hline & & & & \\
\hline
\end{tabular}

15. How much do you spend on maintenance for your car in a year? (In thousands)
$\square$ 0-15
$\square$ 15-30
30-45
$45-60$
60-75
75-90
$\square 90-100$

16. Type of location where you drive your car, tell us in percentage out of $100 \%$ ?

\begin{tabular}{|l|l|l|}
\hline Rural & Urban & Highway \\
\hline & & \\
\hline
\end{tabular}

17. The quality of imported car is:
$\square$ Highly Satisfactory
Satisfactory
$\square$ Neutral
Dissatisfactory
$\square$ Highly Dissatisfactory

18. The quality of local car is:
$\square$ Highly Satisfactory
Satisfactory
$\square$ Neutral
Dissatisfactory
Highly
Dissatisfactory

19. In your opinion which car is more comfortable and durable?
$\square$ Imported
$\square$ Local
$\square$ Both Imported and Local
Neutral

20. To what extent you are conscious about safety features in a car?
$\square$ To great extent
$\square$ To some extent
$\square$ Neutral
Not Conscious

21. What is your priority level for the following safety features?

\begin{tabular}{|c|l|c|c|c|c|}
\hline Sr. No & Safety Features & $1^{\text {st }}$ Priority & $2^{\text {nd }}$ Priority & $3^{\text {rd }}$ Priority & $4^{\text {th Priority }}$ \\
\hline 1 & Anti-lock Braking System & & & & \\
\hline 2 & SRS Airbag & & & & \\
\hline 3 & Cruise Control & & & & \\
\hline 4 & Security System & & & & \\
\hline
\end{tabular}




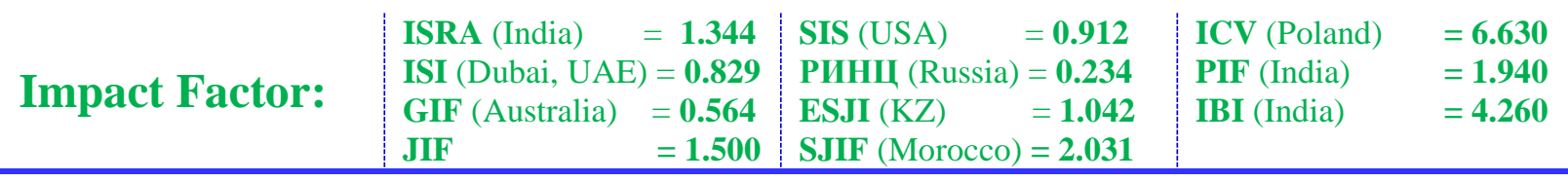

22. In your opinion which car is equipped with more Safety features?
$\square$ Imported
$\square$ Local
Neutral
Both

23. Which of the following Innovative features are more important to you than other?

\begin{tabular}{|c|c|c|c|c|c|c|}
\hline Sr. No & Features & $\begin{array}{c}1^{\text {st }} \\
\text { Priority }\end{array}$ & $\begin{array}{l}2^{\text {nd }} \\
\text { Priority }\end{array}$ & $\begin{array}{c}\mathbf{3}^{\text {rd }} \\
\text { Priority }\end{array}$ & $\begin{array}{c}4^{\text {th }} \\
\text { Priority }\end{array}$ & $\begin{array}{c}5^{\text {th }} \\
\text { priority }\end{array}$ \\
\hline $\mathbf{1}$ & $\begin{array}{l}\text { Automatic } \\
\text { Transmission }\end{array}$ & & & & & \\
\hline 2 & Hybrid Technology & & & & & \\
\hline 3 & Power Steering & & & & & \\
\hline 4 & Push Start & & & & & \\
\hline 5 & Keyless Entry & & & & & \\
\hline 6 & Eco Idle Feature & & & & & \\
\hline 7 & Climate Control & & & & & \\
\hline
\end{tabular}

24. Buying a car is an investment?
$\square$ Strongly Agree
$\square$ Agree
$\square$ Neutral
Disagree
Strongly Disagree

25. To what extent you are conscious about Resale value of car?
$\square$ To great extent
$\square$ To some extent
$\square$ Neutral
Not Conscious

26. Resale value effects your decision of purchasing a car?
Strongly Agree
$\square$ Agree
$\square$ Neutral
Disagree
Strongly Disagree

27. Which car has more resale value?
$\square$ Imported
$\square$ Local
$\square$ Both
$\square$ Neutral

28. Which of the following after sale services for imported vehicle is more important than other?

\begin{tabular}{|c|l|l|l|l|}
\hline Sr. No & After Sale Services & $\mathbf{1}^{\text {st }}$ Priority & $\mathbf{2}^{\text {nd }}$ Priority & $3^{\text {rd }}$ Priority \\
\hline 1 & Mechanics Availability & & & \\
\hline 2 & Spare parts Availability & & & \\
\hline 3 & Cheap spare parts & & & \\
\hline
\end{tabular}

29. After Sale service for local cars is up to the mark: 
\begin{tabular}{l|lr|ll|ll} 
& ISRA (India) & $=\mathbf{1 . 3 4 4}$ & SIS (USA) & $=\mathbf{0 . 9 1 2}$ & ICV (Poland) & $=\mathbf{6 . 6 3 0}$ \\
Impact Factor: & ISI (Dubai, UAE) $=\mathbf{0 . 8 2 9}$ & PUHIL (Russia) $=\mathbf{0 . 2 3 4}$ & PIF (India) & $=\mathbf{1 . 9 4 0}$ \\
& GIF (Australia) & $\mathbf{0 . 5 6 4}$ & ESJI (KZ) & $=\mathbf{1 . 0 4 2}$ & IBI (India) & $\mathbf{= 4 . 2 6 0}$ \\
& JIF & $=\mathbf{1 . 5 0 0}$ & SJIF (Morocco) & $=\mathbf{2 . 0 3 1}$ & & \\
\hline
\end{tabular}

$\square$ Strongly Agree $\square$ Agree $\quad \square$ Neutral $\quad \square$ Disagree $\square$ Strongly Disagree

30. Which car performs better in hilly areas?

$\square$ Imported $\quad \square$ Local $\quad \square$ Both Imported and Local

Neutral

31. Which car performs better on highways?
$\square$ Imported
$\square$ Local
$\square$ Both Imported and Local
Neutral

32. Which car performs better with in city?

$\square$ Imported $\quad \square$ Local $\quad \square$ Both Imported and Local
Neutral

33. According to you which car performs better having same engine power?
$\square$ Imported
$\square$ Local
$\square$ Both are equal
Neutral

34. To what extent you are conscious about fuel consumption of vehicle?
$\square$ To great extent
$\square$ To some extent
Neutral
Not Conscious

35. Which car is more economical with reference to fuel consumption on highways?
$\square$ Imported
$\square$ Local
$\square$ Both are equal
Neutral

36. Which car is more economical with reference to fuel consumption in cities?
$\square$ Imported
$\square$ Local
$\square$ Both are equal
Neutral

37. Have you done market research before purchase decision of car?
$\square$ Yes
$\square$ No
$\square$ Neutral

38. If yes, then from which source you got maximum information?

$\square$ Social Media $\quad \square$ Online information review $\square$ Suggestions from friends and family

$\square$ Other

39. To what extent you compare price of imported and local vehicles while making purchase decision?

$\square$ To great extent $\quad \square$ To some extent $\quad \square$ Neutral $\quad \square$ Don't Compare

40. According to you which vehicle gives you more features according to price?
$\square$ Imported
$\square$ Local
$\square$ Both are equal

$\square$ Neutral

41. Which car will you purchase if you have 1 million?

$\square$ An Imported Used car

$\square$ An Imported New car

$\square$ Locally assembled New car

$\square$ Locally assembled Used car

42. Which car will you purchase if you have 1.5 million? 


\begin{tabular}{l|lr|ll|ll} 
& ISRA (India) & $=\mathbf{1 . 3 4 4}$ & SIS (USA) & $=\mathbf{0 . 9 1 2}$ & ICV (Poland) & $=\mathbf{6 . 6 3 0}$ \\
Impact Factor: & ISI (Dubai, UAE) $=\mathbf{0 . 8 2 9}$ & PUHL (Russia) $=\mathbf{0 . 2 3 4}$ & PIF (India) & $=1.940$ \\
& GIF (Australia) & $\mathbf{0 . 5 6 4}$ & ESJI (KZ) & $=\mathbf{1 . 0 4 2}$ & IBI (India) & $=\mathbf{4 . 2 6 0}$
\end{tabular}

$\square$ An Imported Used car

$\square$ Locally assembled New car

43. Which car will you purchase if you have 2 million?

$\square$ An Imported Used car

$\square$ An Imported New car

$\square$ Locally assembled New car

44. Are you satisfied with your existing car?

$\square$ Highly Satisfied $\quad \square$ Satisfied $\quad \square$ Neutral $\quad \square$ Dissatisfied

$\square$ Locally assembled Used car

$\square$ An Imported New car

Dissatisfied

45. Are you satisfied with the car you own? Kindly rate the satisfaction level of your Ride:

\begin{tabular}{|c|c|c|c|c|c|}
\hline Features & $\begin{array}{c}\text { Highly } \\
\text { Satisfied }\end{array}$ & $\underline{\text { Satisfied }}$ & $\underline{\text { Neutral }}$ & Dissatisfied & $\begin{array}{c}\text { Highly } \\
\text { Dissatisfied }\end{array}$ \\
\hline Price & $\square$ & $\square$ & $\square$ & $\square$ & $\square$ \\
\hline Quality & $\square$ & $\square$ & $\square$ & $\square$ & $\square$ \\
\hline Fuel Efficiency & $\square$ & $\square$ & $\square$ & $\square$ & $\square$ \\
\hline After Sale Services & $\square$ & $\square$ & $\square$ & $\square$ & $\square$ \\
\hline Exterior Design & $\square$ & $\square$ & $\square$ & $\square$ & $\square$ \\
\hline Interior Design & $\square$ & $\square$ & $\square$ & $\square$ & $\square$ \\
\hline Innovation & $\square$ & $\square$ & $\square$ & $\square$ & $\square$ \\
\hline Performance & $\square$ & $\square$ & $\square$ & $\square$ & $\square$ \\
\hline Resale Value & $\square$ & $\square$ & $\square$ & $\square$ & $\square$ \\
\hline Reliability & $\square$ & $\square$ & $\square$ & $\square$ & $\square$ \\
\hline $\begin{array}{l}\text { Environment } \\
\text { Friendly }\end{array}$ & $\square$ & $\square$ & $\square$ & $\square$ & $\square$ \\
\hline
\end{tabular}

Thank you for completing this questionnaire. We appreciate your feedback.! 